\title{
TRADE, TECHNOLOGY, AND \\ WAGE INEQUALITY
}

\author{
Gordon H. Hanson \\ Ann Harrison
}

Working Paper No. 5110

\author{
NATIONAL BUREAU OF ECONOMIC RESEARCH \\ 1050 Massachusetts Avenue \\ Cambridge, MA 02138 \\ May 1995
}

This paper is part of NBER's research program in International Trade and Investment. Any opinions expressed are those of the authors and not those of the National Bureau of Economic Research.

(C) 1995 by Gordon H. Hanson and Ann Harrison. All rights reserved. Short sections of ext, not to exceed two paragraphs, may be quoted without explicit permission provided that full credit, including $\odot$ notice, is given to the source. 
NBER Working Paper \#5110

May 1995

\title{
TRADE, TECHNOLOGY, AND \\ WAGE INEQUALITY
}

\begin{abstract}
In Mexico during the 1980s, the wages of more-educated, more-experienced workers rose relative to those of less-educated, less-experienced workers. We assess the extent to which the increase in the skilled-unskilled wage gap was associated with Mexico's recent trade reform. In particular, we examine whether trade reform has shifted employment towards industries that are relatively intensive in the use of skilled labor (Stolper-Samuelson-type effects). The results suggest that the rising wage gap is associated with changes internal to industries and even internal to plants that cannot be explained by Stolper-Samuelson-type effects. We also find that other characteristics associated with globalization -- such as foreign investment and export orientation -- matter. Exporting firms and joint ventures pay higher wages to skilled workers and demand more skilled labor than other firms.
\end{abstract}

Gordon H. Hanson

Department of Economics

University of Texas

Austin, TX 78712

and NBER
Ann Harrison

Graduate School of Business

Columbia University

New York, NY 10027

and NBER 


\section{Introduction}

During the 1980s, Mexico experienced a dramatic increase in wage inequality. The wages of more-educated, more-experienced workers rose relative to those of less-educated, lessexperienced workers. While such events are worthy of interest in their own right, what makes the change in Mexico's wage structure particularly noteworthy is that it coincided with a sweeping liberalization of trade. In 1985, Mexico announced it was joining the General Agreement on Trade and Tariffs (GATT), bringing an end to four decades of import-substitution industrialization. The government proceeded to drastically reduce most trade barriers in the following three years. It was in 1985 that wage inequality in Mexico began to rise.

In this paper, we assess the extent to which the increase in the skilled-unskilled wage gap in Mexico was associated with the opening of the Mexican economy. A primary motivation for studying the Mexican case is to understand the apparent international trend towards greater wage inequality. Since the 1970s, there has been an increase in wage dispersion in the United States, and, to a lesser extent, in Western Europe.' Whether measured in terms education, experience, or income levels, the wages of skilled workers have increased relative to those of unskilled workers. Several recent studies link the rise in wage inequality to the increasing openness of the U.S. economy, arguing that competition from low-wage countries has reduced the relative demand for unskilled workers and caused their wages to fall relative to those of skilled workers (Leamer 1991, 1994; Wood 1994). Other studies instead associate rising wage inequality with technological change (Davis and Haltiwanger 1991; Bound and Johnson 1992; Lawrence and Slaughter 1993; Berman, Bound, and Griliches 1994). The reasoning is that the advent of

\footnotetext{
' On wage dispersion in the United States, see Davis and Haltiwanger (1991), Bound and Johnson (1992), Juhn, Murphy, and Pierce (1993), and Katz and Murphy (1992); for international evidence, see Davis (1992).
} 
computer technology, and the design and manufacturing applications it has spawned, has made skilled workers increasingly important in the work place. Firms have responded by upgrading the skill level of their employees, displacing low-skilled workers in the process. ${ }^{2}$

The focus of the literature has so far been on developed economies. Wage changes in middle and low-income countries have received comparatively little attention. This is unfortunate. If trade is the force behind relative-wage changes in developed countries, then we should observe corresponding wage movements in developing-country relative wages. For the United States, in particular, we should observe a shrinking of the skilled-unskilled wage gap in its low-wage trading partners. If skill-biased technical change is the cause of relative-wage changes, then we should observe similar wage movements in high-wage and low-wage countries. Given the country's proximity to the United States and its recent opening to trade, Mexico is an ideal candidate in which to look for such changes. ${ }^{3}$

For Mexico, the trade-versus-technology distinction is somewhat misleading. Trade is the vehicle through which new technologies enter most developing countries. This is because most innovations occur abroad and are imported in the form of new machinery and equipment or blueprints for the construction of a factory or the manufacture of a good. The relaxation of trade barriers reduces the price of importing technology from abroad. ${ }^{4}$ The issue, then, is not so much whether trade affects wages, but what are the channels through which trade affects wages.

\footnotetext{
2 Bartel and Lichtenberg ( 1987) and Doms. Dunne, and Troske (1994) find that the adoption of new technology leads to a shift in labor demand towards more skilled workers.

3 Mexico is by no means the only middle-income country to experience a rise in wage inequality in the aftermath of trade reform. Robbins (1993) finds that following trade liberalization in Chile the returns to schooling increased, which contributed to an overall rise in wage inequality.

4 In Mexico, a relaxation of restrictions on foreign technology transfers accompanied the liberalization of trade.
} 
The link that trade theory identifies between trade and wages is embodied in the StolperSamuelson (1941) theorem and its generalizations. ${ }^{5}$ The Stolper-Samuelson logic is that trade affects relative factor rewards by changing relative prices. To explain the observed wage changes in Mexico with this logic, we would need a succession of events such as the following: (1) trade liberalization causes the prices of skilled labor-intensive goods to rise relative to those of unskilled labor-intensive goods; (2) the price changes reduce the demand for labor in unskilledintensive industries and increase the demand for labor in skill-intensive industries; and (3) the employment shift towards skill-intensive industries contributes to an increase in the relative demand for skilled workers, causing their wages to increase relative to those of unskilled workers.

This story is consistent with two alternative hypotheses. First, Mexico is abundant in skilled labor and scarce in unskilled labor relative to the rest of the world. While Mexico is surely not abundant in skilled labor relative to the United States, it may be so relative to lowincome countries, such as China. Second, Mexico may have protected industries with a high share of unskilled labor. Although this possibility seems at odds with its expected comparative advantage in unskilled labor, political economy considerations may have led the government to protect sectors where the country was most competitive. In either case, the Stolper-Samuelson explanation for the observed trends implies that (1) the relative prices of skill-intensive goods will have increased, and (2) there will have been a shift in employment towards skill-intensive sectors.

Other explanations for the rise in wage inequality in Mexico focus on factors which are often internal to industries or firms, such as technological change. Changes in trade policy could indirectly affect the demand for skilled labor by giving the country access to new technology,

\footnotetext{
s See Ethier (1984) for a discussion of the literature on generalizations of the Stolper-Samuelson theorem, and see Lawrence and Slaughter (1993) and Leamer (1994) for discussions of Stolper-Samuelson and relative wages.
} 
embodied in imported capital goods. A more open economic environment could lead to surges in foreign direct investment and exports. If foreign firms and exporters demand more skilled workers, due to more advanced technology or differing product mixes, then this too could explain a shift towards skilled employees.

Recent literature on Mexican labor markets has yet to identify a link between trade and wage inequality. Feliciano (1993) and Craig and Epelbaum (1995), both using household-level data, find that the return to schooling increased in Mexico during the late $1980 \mathrm{~s}$. Revenga (1994), who uses plant-level data, finds that blue-collar wages and employment are more responsive to changes in protection than those of white-collar workers. Bell (1994) studies the impact of minimum wages on labor demand in Mexico over the period 1984 to 1990 . She finds that for medium and large manufacturing plants minimum wages had no impact on labor demand. This is attributed to the fact that for most plants the minimum wage was not binding during the period. This finding is important since it implies that the dramatic decline in Mexico's minimum wages in the 1980 s cannot account for the increase in wage inequality.

The body of the paper has four sections. Section II describes the wages and employment of skilled and unskilled workers in Mexico before and after trade reform. Section III uses industry data on relative prices and employment to evaluate the effects of trade on relative wages. Section IV examines the sectoral and plant-level determinants of wage inequality and the relative demand for skilled and unskilled labor. Section V offers concluding remarks.

\section{Relative Wages and Employment in Mexico}

Data are available from two sources. We have annual data on 2,354 Mexican 
manufacturing plants for the period 1984 to 1990 from the Secretariat of Trade and Industrial Promotion (SECOFI). The SECOFI sample is the only plant-level data available in Mexico. It is fortunate for our purposes that the sample period spans the implementation of trade reform. One source of concern is that by design the sample covers only medium and large plants. ${ }^{6}$ In 1986, average workers per establishment was 321 in the SECOFI sample, compared to 67 in all manufacturing establishments. To ensure that the empirical regularities we identify in the SECOFI sample are representative of Mexican industry as a whole, we also use data from the Mexico Industrial Census. We have Census data on employment, number of establishments, and total payroll by state and two-digit (ISIC) industry for the period 1965 to 1988 , at five-year intervals. To a first approximation, the SECOFI sample is representative of the overall mix of industrial activity in Mexico. Table 1 shows that the distribution of employment across two-digit (ISIC) industries in the SECOFI sample and in the Industrial Census are nearly identical.

One issue before turning to the data is how to measure wages. To identify the effect of trade on relative wages, we must be able to distinguish workers by skill level. The SECOFI sample and the Industrial Census classify workers in two categories: obreros, who are equivalent to blue-collar workers, and empleados, who are equivalent to white-collar workers. The activities of blue-collar workers include machine operation, production supervision, repair, maintenance, and cleaning; those of white-collar workers include management, product development, administration, and general office tasks. We identify white-collar workers as skilled labor and blue-collar workers as unskilled labor. We measure earnings as the average annual salary or average hourly wages for each type of worker in a given plant. The white collar-blue collar

6 In 1989, the SECOFI plants accounted for 29 percent of total manufacturing employment, as measured by the Mexico Industrial Census. 
distinction has obvious limitations, but the substantial wage differences between the two types of workers suggests that the classification is a useful definition. ' There is no data for Mexico that provide a more detailed plant-level breakdown of employment by type and by industry.

\section{A. The Liberalization of Trade}

To frame the discussion, we begin by considering the dimensions of trade reform in Mexico. Mexico's economy was largely closed to trade from the 1950 s until the mid 1980 s. The government initiated a conscious policy of trade protection in the late 1940s, when it raised tariffs and instituted a system of import licenses. Successive administrations expanded trade barriers, mainly by increasing the range of goods covered by import licenses. These licenses gave the government the discretion to impose import quotas at will. The government also used export controls to direct production towards the domestic market.9

The government decided to open the economy to trade in 1985 . It moved swiftly, drastically lowering most trade barriers within three years. In mid 1985, the national average tariff was 23.5 percent, and import-license requirements covered 92.2 percent of national production. By December 1987, import-license coverage had been reduced to 25.4 percent of national production and the average tariff had been reduced to 11.8 percent, with a maximum rate

\footnotetext{
? Berman, Bound and Griliches (1994) provide evidence for the United States which suggests that the white collar-blue collar classification works well as a division of the labor force by skill.

A A second problem with the blue collar-white collar classification is that neither data source breaks down nonwage compensation by worker type. Our measure of compensation excludes non-wage payments. This omission does not appear to be too egregious, as wages account for the majority of payments to workers. In the SECOFI sample, the wage share of total compensation was 0.71 in 1984 and 0.69 in 1990; in the Industrial Census, the wage share of total compensation was 0.73 in both 1985 and 1988.
}

In 1980, Mexico had export controls on 85 percent of non-oil exports. 
of 20 percent. Concurrent with reform, the government abolished export controls and devalued the nominal exchange rate. Table 2 shows annual production-weighted-average tariffs and import-license coverage by two-digit (ISIC) industry for the period 1984-1990. In 1985, the average tariff ranged from 13.6 percent in basic metals to 47.3 percent in wood products; import licenses were required for over 85.0 percent of products in all two-digit industries. The government first cut import-license requirements, reducing average import-license coverage to below four percent by 1988 in all industries except food products and metal products. The government then proceeded to reduce tariffs; by 1989 , the maximum tariff rate in any industry was in wood products at 17.6 percent. The only industry that continues to enjoy relatively high rates of protection is metal products, due mainly to import restrictions on automobiles.

\section{B. Wages and Employment}

Since 1984, there has been a dramatic increase in wage inequality for manufacturing workers in Mexico. Table 3 shows average real wages and average relative wages for the SECOFI sample of plants..$^{10}$ Between 1984 and 1990, the ratio of average hourly white-collar and blue-collar wages increased from 1.93 to 2.55 ; the ratio of average annual white-collar and blue-collar earnings showed a similar change, increasing from 1.91 to 2.47 . The rise in the skilled-unskilled wage differential was due to a combination of real-wage increases for whitecollar workers and real-wage decreases for blue-collar workers. Between 1984 and 1990, real average hourly wages for white-collar workers increased by 13.4 percent, while those for blue-

\footnotetext{
${ }^{10}$ Real wages are calculated as nominal annual remunerations per worker and per hour worked, deflated by the June consumer price index in a given year. Wage levels are 1980 pesos. All figures are weighted averages, where weights are the plant share of national employment or hours.
} 
collar workers decreased by 14.0 percent. $^{11}$

The Industrial Census shows similar movements in the white collar-blue collar wage gap. Figure 1 plots the ratio of average annual white-collar wages to average annual blue-collar wages for the period 1965 to 1988 . Between 1985 and 1988 , the white collar-blue collar wage ratio rose from 1.84 to 2.16 , which matches the movements in the SECOFI sample over the same time period. Of greater significance, the rise in the wage gap after 1985 appears to have halted a twodecade trend towards decreasing wage inequality. ${ }^{12}$

While the white collar-blue collar wage gap increased in all industries, there is considerable inter-industry variation in relative wages. Table 4 shows average relative wages for the SECOFI sample by two-digit industry in 1984 and 1990. In 1990, the hourly wage ratio varied from 1.96 in textiles and apparel (ISIC 32) to 3.06 in stone, clay, and glass (ISIC 36). There was also considerable inter-industry variation in relative-wage changes. The largest changes occurred in heavy industries -- iron and steel (ISIC 37), stone, clay, and glass (ISIC 36), and paper (ISIC 34). Table 5 shows that similar patterns hold for the Industrial Census.

Table 6 shows the ratio of white-collar to blue-collar employment for the SECOFI sample. Between 1984 and 1990, there was virtually no aggregate change in relative employment. The ratio of white-collar to blue-collar employment increased from 0.431 to 0.433 ; the ratio of whitecollar to blue-collar hours worked decreased from 0.427 to 0.421 . Industry-level data also fail

"The total change for the period masks large real-wage swings that occurred within the period. Real whitecollar wages declined by 16.1 percent between 1985 and 1988, and then increased, surpassing their 1985 levels by 1989. What the real-wage swings may reflect is unanticipated inflation in 1986 and 1987 . While unexpected inflation can account for a temporary decline in wages for both types of workers, it cannot account for the increase in the white collar-blue collar wage gap over the period.

12 The wage changes we report are also consistent with household-level data on wage changes in Mexico over the same period reported in Feliciano (1993), Bell (1994), and Craig and Epelbaum (1995). 
to indicate substantial changes in relative employment. Table 7 shows relative employment by two-digit industry for the SECOFI sample in 1984 and 1990. Four industries experienced an increase in the relative employment of white-collar labor, while five industries experienced a decline. Of the three industries with the largest changes in relative wages, only iron and steel showed an increase in relative white-collar employment of more than 0.014 .

The Industrial Census shows somewhat larger changes in relative employment. Figure 2 plots the ratio of white-collar employment to blue-collar employment for the period 1965 to 1988. The ratio fell from 0.346 in 1985 to 0.328 in 1988 . Table 5 shows relative employment by two-digit industry for the Industrial Census in 1985 and 1988. Seven industries showed a decline in relative white-collar employment, while two industries showed an increase.

One possible explanation for the rising skill premium is that the supply of skilled labor shifted to other sectors or migrated abroad. There is no evidence, however, which suggests that the composition of Mexican emigrants changed over the 1980s. Borjas (1994) finds that the average years of schooling of Mexican immigrants arriving between 1980 and 1990 was the same as that of pre-1980 arrivals. The average education level of Mexican immigrants in the United States is the lowest of all major source countries. Borjas also finds that during the 1980 s the wages of Mexican immigrants in the United States declined relative to those of ethnically similar U.S. natives. This suggests that, if anything, there was an increase in the relative emigration of unskilled workers from Mexico during the 1980s. There is also little evidence of a shift of employment out of manufacturing into other sectors. The manufacturing share of the total labor force increased during the 1980 s, rising from 16.7 percent in 1980 to 19.9 percent in 1988 . 


\section{The Heckscher-Ohlin Theorem: Industry Composition and Wages}

The evidence presented in Section II shows strong evidence of an increase in the skilledunskilled wage gap in Mexico following the liberalization of trade. One explanation for this shift would be that trade increased the return to Mexico's abundant factor -- skilled labor. This is the Stolper-Samuelson theorem. In this section, we search for more detailed evidence consistent with Stolper-Samuelson-type effects.

\section{A. Relative Prices, Sectoral Employment, and Trade}

A standard trade theory explanation for the effects of trade on relative wages involves the transmission of relative-price changes to industry labor demand and relative factor rewards. The Stolper-Samuelson effect outlined in the introduction implies we should observe the following: (1) an increase in the relative price of skill-intensive goods, (2) a shift in employment towards skill-intensive sectors, and (3) a decrease in the relative employment of skilled labor within each industry (in response to the relative-wage changes).

Relative Prices and Skill Intensity. To determine if relative-price changes correspond to the observed relative-wage changes, we consider the correlation between relative-price changes and relative skill intensity. In a many good, many factor world, there is no general definition of relative factor intensity. The crude measure of skill intensity we use is the ratio of white-collar to blue-collar employment. If relative-price increases in skill-intensive sectors account for the increasing returns to skill, then we should see a positive relationship between skill-intensity and price increases in the 1980s. Figures $3 \mathrm{a}$ and $3 \mathrm{~b}$ plot the change in log prices between 1984 and 1990 against the log ratio of blue-collar to white-collar employment in 1984 at the four-digit 
level. In Figure 3a, employment is measured in number of workers; in Figure 3b, employment is defined in terms of total hours. Our measure of industry price is a four-digit producer price index, deflated by the wholesale price index. We find no significant correlation, positive or negative, between relative-price changes and skill intensity. ${ }^{13}$ The result holds for employment measured in terms of workers or hours.

Reallocation of Employment and Skill Intensity. Strictly speaking, the Stolper-Samuelson effect does not require that trade reallocate labor across industries. Relative-price changes alone are sufficient to generate changes in relative factor awards. Nevertheless, if the relative prices of skill-intensive goods rose, we would expect some reallocation of labor towards those sectors. Despite the magnitude of trade reform, there was little employment reallocation across industrial sectors. Table 8 shows industry shares of national employment by type of worker for 1984 and 1990. The largest relative-employment declines occurred in textiles and apparel (ISIC 32), whose share of total manufacturing employment fell from 0.128 to 0.112 , and iron and steel (37), whose employment share fell from 0.075 to 0.061 ; these two industries also experienced a decline in absolute employment over the period. The largest relative employment increases occurred in food products (ISIC 31), whose employment share increased from 0.195 to 0.214 , and metal products (ISIC 38), whose employment share increased from 0.266 to 0.280 ; these two industries

13 This result is surprising, perhaps, given that prior to trade reform Mexico appeared to afford greater trade protection to unskilled-labor intensive sectors. There is a negative and statistically significant relationship between output tariffs and skill intensity, measured at the four-digit level for 1984. There is also a negative, but statistically insignificant, relationship between tariff changes over the period 1984-1990 and skill intensity in 1984. We might expect, then, for relative-price increases to have been largest in skilled-labor intensive industries. Output tariffs, however, give an incomplete measure of the structure of protection, since they do not take into account the effect of input tariffs or input and output quotas (where quotas result from the imposition of import licenses). There is a positive correlation between output tariffs and import licenses on outputs at the four-digit level in 1984 (the correlation coefficient is $\mathbf{0 . 4 0}$ ), but import licenses only show where the government had the opportunity to impose quotas. They do not show true quota levels or whether quotas were binding. 
experienced absolute employment growth over the period. The changes in industry employment shares occurred almost entirely from changes in relative blue-collar employment; the distribution of white-collar employment across industries stayed nearly constant over the period. Figures for total hours give similar results.

Even though the changes in industrial composition following trade reform were small, we want to know if the industries that experienced the largest employment growth were those that are relatively intensive in the use of skilled labor. To determine if there was a shift in employment towards skill-intensive sectors, we ask whether employment growth was higher in sectors that employed a relatively high share of white-collar workers. Figures $4 a-5 b$ plot the change in log employment of white-collar and blue-collar workers between 1984 and 1990 against the ratio of white-collar to blue-collar employment in 1984 , by four-digit industry. We again measure employment in terms of the number of workers and total hours. There is no apparent relationship between initial skill intensity and employment growth, suggesting that there has not been an employment shift towards industries that are relatively intensive in skilled labor. Nor do we find any evidence that the relative employment of unskilled labor has increased within industries. Table 7 shows that there was no tendency for industries to reduce the relative employment of white-collar workers over the sample period.

Mexico's Comparative Advantage. Further evidence consistent with a Stolper-Samuelson explanation of the increase in the relative wages of skilled workers would be that Mexico has a comparative advantage in goods which are relatively intensive in the use of skilled labor. Figures $6 \mathrm{a}$ and $6 \mathrm{~b}$ show the relationship between export orientation at the 4-digit level and the share of white-collar relative to blue-collar employment in each sector. Export orientation is measured 
as the fraction of sales which are shipped to foreign countries. The relationship between export orientation and skill intensity is positive but statistically insignificant. Revenga (1995) also examines the relationship between skill-intensity and export orientation, but uses net exports as a measure of comparative advantage. Revenga finds that net exports are negatively correlated with skill-intensity -- suggesting that Mexico has a comparative advantage in goods which use unskilled labor more intensively. Based on these results, we cannot conclude that Mexico has a comparative advantage in goods which use skilled labor intensively.

\section{B. Decomposing Relative Wage Changes}

Relative-wage, relative-price, and relative-employment changes do not correspond in the manner predicted by standard trade theory. In this section, we examine the extent to which relative-wage changes were primarily due to shifts in employment between sectors versus changes within sectors. Since trade policy is implemented at the sector level, it is a valid explanation for increasing wage inequality only if most wage changes occurred between, and not within, sectors.

The white-collar share of total wages for all manufacturing industries can be written as the weighted sum,

$$
\operatorname{WSH}=\sum_{i} \mathrm{p}_{i} \operatorname{WSB_{i}}
$$

where $W S H$ is the white-collar share of total wages in all manufacturing, $W S H_{i}$ is the whitecollar wage share in industry $i$, and $\rho_{i}$ is industry $\vec{i}$ s share of total wages. By taking changes in the proportion, we obtain the following expression: 


$$
d W S B=\sum_{i} \bar{p} d W S E_{i}+\sum_{l} d p_{l} \overline{W_{S H}}
$$

where $d$ represents the change over the period and a bar represents the mean value for the period. The first expression is the change in the white-collar wage share due to relative-wage changes within industries; the second expression is the change in the white-collar wage share due to between industry shifts in employment.

We perform the decomposition using both the SECOFI sample and the Industrial Census. The results are given in Table 9 . For the SECOFI sample, 80 percent of the change in the whitecollar wage share is due to within-industry relative-wage changes; for the Industrial Census, 93 percent of the change is due to within-industry changes. The fact that between industry employment shifts account for a small share of the change in relative wages should not be surprising, given the lack of inter-industry employment shifts that occurred over the period.

One additional channel through which trade can affect relative wages is by shifting employment towards plants that are relatively intensive in the use of skilled labor. Inter-plant employment shifts, in principle, are capable of causing relative wage changes without affecting the distribution of employment across industries. To pursue this idea, we perform a decomposition of the change in the white-collar wage share into the portion due to within plant changes in relative wages and the portion due to between plant shifts in employment. The decomposition is analogous to the industry decomposition above. The results are also given in Table 9. Similar to the industry-level findings, we find that most of the change in relative wages was due to changes within plants. The change in the white-collar wage share due to betweenplant shifts in employment was only 27 percent.

The results on wage and employment reallocation in Mexico suggest that most of the 
movements in the variation of skilled and unskilled wages and employment occurred within, and not between, industries. Since trade policy changes were implemented across sectors, and not within industries or firms, this suggests that trade policy does not play the major role in explaining the observed changes in wage inequality. Since the Stolper-Samuelson theorem concerns shifts across industries, and not within industries, we turn below to other explanations for observed wage and employment behavior.

\section{Explaining the Variation in Wages and Employment Across Sectors and Plants}

The results above suggest that standard explanations associated with trade theory cannot adequately account for the increase in the skilled-unskilled wage gap in Mexico during the 1980s. In this section, we explore the extent to which skilled-unskilled wage differentials and skill intensity in employment reflect trade policies as well as other factors, such as the changing availability of inputs, foreign ownership, and export orientation. One frequent alternative explanation for increasing wage inequality is skill-biased technological change. We introduce a number of alternative measures which capture changes in technology, which vary both across firms and sectors. The fact that trade policies varied only across sectors while measures of technological change are available at the plant level allow us to disentangle the effects of trade policies and technology. We also account for other factors which could explain inequality, such as plant size and other (non-wage) benefits paid to employees.

Appendix Table A.l lists the variables included in the analysis and variable definitions. Variables which capture technological change -- either disembodied or embodied in capital goods -- include the share of imported machinery in total machinery purchases, the share of imported 
materials in total material purchases, the equipment and transport shares in total investment, total factor productivity growth, and royalty payments for patents, copyrights or trademarks as a share of total sales. Other factors included in the analysis which may be related to technological change (as well as trade policy) are export orientation and foreign investment share.

We also include nonwage payments in the analysis, to determine whether wage inequality is related to employer contributions for non-wage payments. Unfortunately, since non-wage payments (such as social security contributions or payroll taxes) are not available separately for skilled and unskilled workers (see note 8), we cannot assess the extent to which using wages or total employer costs affects the observed shift in the returns to skill. Finally, we also include plant size and capital-labor ratios by quintile. The excluded categories are the classification for small firms (1-50 workers) and the first quintile of the capital-labor ratio.

Table 10 reports relative wages and relative employment at the sector level, with variables aggregated across all plants within each four-digit manufacturing sector. Relative wages are defined as the $\log$ ratio of white-collar to blue-collar average annual wages; relative employment is defined as the log ratio of white-collar to blue-collar employment. Our two measures of employment are total number of white (blue) collar employees and total hours worked by white (blue) collar employees. Wages are defined as total wages paid in the industry divided by either the total number of employees or total hours worked. To control for industry and regional factors that influence relative wages, and relative employment, we also include two-digit industry

dummies, state dummies, and year dummies in the analysis.

At the sector level, neither capital-labor ratios nor average plant sizes are significant in explaining cross-sector variation in wages. However, both export orientation and foreign 
investment shares are positively and significantly correlated with greater wage inequality. Proxies for technological change, such as royalty payments, imported machinery, or total factor productivity growth, are either negatively associated with skilled wages or insignificant. The only other variables that are significantly associated with the skilled-unskilled wage gap are social security payments, other non-wage costs, and profit sharing.

A larger share of social security payments and other non-wage costs in total payroll are associated with smaller wage differentials between skilled and unskilled workers. There are several possible explanations. If skilled workers tend to be paid social security, while compliance is poor for unskilled workers, then skilled workers are being partly compensated with a shifting of the social security tax obligation towards skilled workers through lower wages. Another possibility is that industries which adhere to labor law -- paying minimum wages, social security, and other benefits -- are being squeezed and respond by compressing the overall pay scale.

The last two columns in Table 10 examine the determinants of the skilled-unskilled labor employment ratio across sectors. Industries with a high share of foreign plants hire a significantly larger share of skilled workers, as do industries which are more capital intensive (but not the most capital-intensive). High social security payments and non-wage benefits are negatively associated with the share of skilled workers. Other variables which are significantly and negatively correlated with skill intensity include the equipment share in investment and tariffs. The negative coefficient on tariffs suggests that tariffs were highest in sectors with a higher share of unskilled labor (see note 13). Variables which are positively associated with skill intensity include imported raw materials, investment in transport, and royalty payments.

Table 11 redoes the analysis at the plant level. Wage inequality is positively and 
significantly associated with larger plant sizes, greater capital intensity, foreign ownership and export orientation. As in the sector-level results, wage inequality is negatively associated with social security and non-wage costs in the total wage bill. The results on foreign investment and export orientation suggest that globalization is important, but that tariff and quota changes per se do not capture the effects of these changes. We also redid the analysis excluding foreign investment and exports, to test whether trade reforms had affected relative wages indirectly through their impact on exports and investment. However, we found no change in the impact of the trade policy variables on wages or employment.

The last two columns of Table 11 examine relative employment at the plant level. Medium-sized plants and capital-intensive plants employ a greater share of skilled workers, as do foreign-owned enterprises. Exporting plants, however, do not employ a higher share of skilled relative to unskilled workers, despite paying relative high wages to skilled labor. Equipment investment and imported machinery, which are negatively and significantly associated with skill intensity, appear to substitute for skilled labor. Corroborating sector-level evidence, tariffs, social security and non-wage benefits are significantly and negatively correlated with skill intensity.

The results in Table 10 and 11 show that the most important determinants of wage inequality are capital intensity, export orientation, the foreign investment share, and non-wage costs. It has been well-documented that foreign firms tend to pay workers higher wages (Lipsey 1994; Aitken, Harrison, and Lipsey 1994). What our results show is that the foreign-firm premia is larger for skilled workers than it is for unskilled workers. Similar results hold for exporters. This suggests that within-industry heterogeneity across firms may be a factor in explaining the increased skilled-unskilled wage gap in Mexico. To the extent that foreign firms and firms with 
the capacity to export are better situated to compete in an open economy, then trade liberalization will shift resources towards these firms, leading to an increase in the skilled-unskilled wage gap. The recent influx of foreign capital into Mexico is consistent with this reasoning. Concomitant to trade reform in Mexico, there was a liberalization of regulations governing foreign investment which lead to a substantial increase in foreign direct investment in the country. Feenstra and Hanson (1995) report that the share of foreign direct investment in total investment increased from 1.42 percent in 1983 to 9.68 percent in 1989 . Using regional industry data, they also find a positive correlation between relative wages and foreign investment.

It is also striking that there is no evidence that industries or plants that engage in technological upgrading -- as evidenced by royalty payments for foreign technology, total factor productivity growth, or the share of imported machinery in investment -- have a higher skilledunskilled wage gap. This is evidence against skill-biased technical change as an explanation for rising wage inequality in Mexico. This result is of interest, given mounting evidence for the United States which suggests that some portion of the increase in the relative demand for skilled labor is due to technological change. The lack of such evidence for Mexico may be due to a slow rate of diffusion of new technologies across borders. If the technological advancements which have occurred in the United States are eventually transferred to Mexico, the increase in the skilled-unskilled wage gap which has occurred thus far will only be compounded.

\section{Concluding Remarks}

In this paper we examine changes in the relative wages and relative employment of skilled and unskilled workers in Mexico that followed the country's 1985 trade reform. Since trade 
reform, there has been a dramatic increase in the skilled-unskilled wage gap. The relative-wage changes have occurred without large changes in relative employment. A primary concern of the paper has been to search for effects of trade reform on relative prices and the sectoral distribution of labor that could explain the relative-wage changes.

We find little evidence of a correlation between relative-price changes and skill intensity or between industry employment growth and skill intensity that could plausibly account for the increase in the skilled-unskilled wage gap. There is no significant correlation between skill intensity and relative producer price changes during the 1980s, nor is there any evidence that Mexico had a comparative advantage in skill-intensive goods.

More generally, we find strong evidence that the changes in Mexico's relative-wage structure are associated with changes internal to industries and plants. Since trade reforms were implemented at the sector level, this suggests that other factors were responsible for the observed increase in wage inequality. Broadening the scope of the analysis, we find that foreign plants and exporters paid relatively higher returns to skilled workers. Greater integration into the world economy did play a role in explaining the observed increase in income inequality, but the mechanism was not exclusively through lower tariffs or quotas. We also examine the extent to which technological change -- captured at the plant level by royalties paid for the use of patents and copyrights, machinery imports, and productivity growth -- can account for the higher return to skilled labor. There is no strong evidence in favor of the technology hypothesis. 


\section{References}

Aitken, B., A. Harrison, and R.E. Lipsey. 1994. "Wages and Foreign Ownership: A Comparative Study of Mexico, Venezuela, and the United States."

Bartel, A.P., and F.R. Lichtenberg. 1987. "The Comparative Advantage of Educated Workers in Implementing New Technology." Review of Economics and Statistics 69: 1-11.

Bell, LA. 1994. "The Impact of Minimum Wages in Mexico and Columbia." Presented at the World Bank Labor Markets Workshop, July 1994.

Berman, E., J. Bound, and Z. Griliches. 1994. "Changes in the Demand for Skilled Labor within U.S. Manufacturing: Evidence from the Annual Survey of Manufacturers." Quarterly Joumal of Economics 109: 367-398.

Bernard, A.B. and J.B. Jensen. 1994. "Exporters, Skill Upgrading, and the Wage Gap." Mimeo, MIT and Bureau of the Census.

Borjas, G.J. 1994. "The Economics of Integration." Joumal of Economic Literature 32: 16671717.

Bound, J. and G. Johnson. 1992. "Changes in the Structure of Wages in the 1980s: An Evaluation of Alternative Explanations." American Economic Review 82: 371-92.

Borjas, G.J. and V.A. Ramey. 1993. "Foreign Competition, Market Power, and Wage Inequality: Theory and Evidence." NBER Working Paper No. 4556.

Craig, M.I. and M. Epelbaum. 1995. "The Premium for Skills in LDCs: Evidence from Mexico." Mimeo, Columbia University and ITAM.

Davis, S.J. 1992. "Cross-Country Patterns of Change in Relative Wages." In O. Blanchard and S. Fischer, eds., NBER Macroeconomics A nnual 1992.

Davis, S.J. and J. Haltiwanger. 1991. "Wage Dispersion between and within U.S. Manufacturing Plants, 1963-86." Brookings Papers on Economic Activity: Microeconomics 1991.

Doms, M., T. Dunne, and K. Troske. 1994. "Workers, Wages, and Technology." Mimeo, University of Oklahoma.

Ethier, W.J. 1994. "Higher Dimensional Issues in Trade Theory." In R.W. Jones and P.B Kenen, eds., Handbook of Intemational Economics, Amsterdam: North-Holland.

Feliciano, Z. 1993. "Workers and Trade Liberalization: The Impact of Trade Reforms in Mexico on Wages and Employment." Mimeo, Harvard University. 
Feenstra, R.C. and G.H. Hanson. 1995. "Foreign Investment and Relative Wages: Evidence from Mexico's Maquiladoras." NBER Working Paper No.

Juhn, C., K.M. Murphy, and B. Pierce. 1992. "Wage Inequality and the Rise in Returns to Skill." Joumal of Political Economy 101: 410-442.

Katz, L. and K.M. Murphy. 1992. "Changes in Relative Wages, 1963-1987: Supply and Demand Factors." Quarterly Joumal of Economics 107: 35-78.

Lawrence, R.Z. and M.J. Slaughter. 1993. "Trade and U.S. Wages: Great Sucking Sound or Small Hiccup?" Presented at MICRO-BPEA Meeting, June 1993.

Leamer, E. 1993. "Wage Effects of a U.S.-Mexico Free Trade Agreement." In P.M. Garber, ed., The Mexico-U.S. Free Trade Agreement, Cambridge: MIT Press.

Leamer, E. 1994. "Trade, Wages, and Revolving Door Ideas." NBER Working Paper No. 4716.

Lipsey, R.E. 1994. "Foreign-Owned Firms and U.S. Wages." NBER Working Paper No. 4927.

Revenga, A. 1994. "Employment and Wage Effects of Trade Liberalization: The Case of Mexican Manufacturing." Presented at the World Bank Labor Markets Workshop, July 1994.

Revenga, A. 1995. "North American Integration and Factor Price Equalization: Is There Evidence of Wage Convergence between Mexico and the United States?" Mimeo, World Bank.

Roberts, M.J. and E. Skoufias. 1994. "The Long Run Demand for Skilled and Unskilled Labor in Columbian Manufacturing Plants." Mimeo, Pennsylvania State University and University of Colorado.

Robbins, D. 1993. "Relative Wage Structure in Chile: The Effects of Liberalization." Mimeo, HIID.

Stolper, W. and P.A. Samuelson. "Protection and Real Wages." Review of Economic Studies, November 1941, 51-68.

Tybout, J. and D. Westbrook. 1994. "Trade Liberalization and the Dimensions of Efficiency Change in Mexican Manufacturing Industries." Mimeo, Georgetown University.

Wood, A. 1994. North-South Trade, Employment, and Inequality. Oxford: Clarendon Press. 
Appendix: Table A.1 Variable Definitions

Yariable

Capital-Labor Ratio

Export Share

Foreign Share

Social Security

Other Non-wage Costs

Profit-Sharing

Imported Machinery

Imported Materials

Equipment Share in Investment

Transport Share

in Investment

Export (Plant Dummy)

Foreign (Plant Dummy)

Total Factor

Productivity Growth

Royalty Payments

Output tariff

Output quota*

- Industry refers to four-digit MEXSIC classification. investment.

Royalties paid/Sales.

\section{Definition}

Reported capital stock valued at replacement rates (deflated by the PPI) / Number of Employees.

Sectoral share of total sales going to export markets.

Sectoral share of total employment in foreign owned enterprises, with employment in foreign enterprises weighted by foreign-equity share.

Share of social-security contributions by the plant in total payroll costs.

Share of non-wage costs paid by the plant in total payroll costs.

Profit-sharing as a fraction of total payroll costs.

Share of imported machinery in total machinery purchases.

Share of imported material inputs in total material inputs.

Share of new and used equipment purchases, as well as goods produced for own use or improved by third parties, in total investment.

Share of new and used transport purchases, as well as produced for own use produced for own use or improved by third parties, in total

Equals one if plants has positive exports.

Equals one if plant has positive foreign equity participation (Plant FDI: USA, Plant FDI: Japan etc. equal one if plant has positive foreign equity from indicated country).

Percentage change in real output less weighted changes in material inputs, capital inputs, and number of employees, with weights given by the share of these inputs in total sales. Real output is defined as sales deflated by a four-digit product price deflator. Material inputs are deflated by a material price deflator.

Average tariff (\%) on outputs by four-digit industry.

Average share of outputs subject to import-license requirement by four-digit industry. 
Table 1: Employment Shares by Two-Digit Industry, 1986

\begin{tabular}{|c|c|c|c|c|}
\hline ISIC Code & $\begin{array}{r}\text { Indus } \\
\text { No. of Estab } \\
\end{array}$ & $\begin{array}{l}\text { trial Census } \\
\text { Indus. Employ, Share }\end{array}$ & $\underline{\text { No. }}$ & $\begin{array}{l}\text { FI Sample } \\
\text { Indus. Employ. Share }\end{array}$ \\
\hline 31 & 46,866 & .2005 & 395 & .2036 \\
\hline 32 & 15,794 & .1531 & 305 & .1374 \\
\hline 33 & 15,275 & .0485 & 67 & .0153 \\
\hline 34 & 6,793 & .0507 & 167 & .0547 \\
\hline 35 & 4,688 & .1582 & 480 & .1812 \\
\hline 36 & 9,320 & .0543 & 149 & .0662 \\
\hline 37 & 1,015 & .0473 & 62 & .0459 \\
\hline 38 & 28,417 & .2778 & 474 & .2894 \\
\hline 39 & 1,237 & .0097 & 27 & .0065 \\
\hline
\end{tabular}

Source: Authors' calculations based on Industrial Census and SECOFI sample data. 
Table 2: Average Tariffs and Import-License Requirements by Two-Digit Industry, 1984-90 (percent)

\begin{tabular}{|c|c|c|c|c|c|c|c|c|}
\hline Industry & & 1984 & 1985 & 1986 & 1987 & 1988 & 1989 & 1990 \\
\hline $\begin{array}{l}\text { 31-Food } \\
\text { Products }\end{array}$ & $\begin{array}{l}\mathrm{t} \\
\mathrm{q}\end{array}$ & $\begin{array}{r}42.9 \\
100.0\end{array}$ & $\begin{array}{l}45.4 \\
80.1\end{array}$ & $\begin{array}{l}32.1 \\
62.2\end{array}$ & $\begin{array}{l}22.9 \\
33.3\end{array}$ & $\begin{array}{l}14.8 \\
20.8\end{array}$ & $\begin{array}{l}15.8 \\
20.6\end{array}$ & $\begin{array}{l}16.2 \\
16.8\end{array}$ \\
\hline $\begin{array}{l}\text { 32-Textiles, } \\
\text { Apparel }\end{array}$ & $\mathrm{t}$ & $\begin{array}{l}38.6 \\
92.9\end{array}$ & $\begin{array}{l}43.2 \\
66.8\end{array}$ & $\begin{array}{l}40.4 \\
38.0\end{array}$ & $\begin{array}{l}26.6 \\
31.1\end{array}$ & $\begin{array}{c}16.8 \\
2.8\end{array}$ & $\begin{array}{c}16.6 \\
1.1\end{array}$ & $\begin{array}{c}16.7 \\
1.0\end{array}$ \\
\hline $\begin{array}{l}\text { 33-Wood } \\
\text { Products }\end{array}$ & $\begin{array}{l}\mathrm{t} \\
\mathrm{q}\end{array}$ & $\begin{array}{c}47.3 \\
100.0\end{array}$ & $\begin{array}{l}48.5 \\
75.6\end{array}$ & $\begin{array}{l}44.9 \\
25.7\end{array}$ & $\begin{array}{c}29.9 \\
0.0\end{array}$ & $\begin{array}{c}17.7 \\
0.0\end{array}$ & $\begin{array}{c}17.6 \\
0.0\end{array}$ & $\begin{array}{c}17.8 \\
0.0\end{array}$ \\
\hline $\begin{array}{l}\text { 34-Paper, } \\
\text { Printing }\end{array}$ & $\begin{array}{l}\mathrm{t} \\
\mathrm{q}\end{array}$ & $\begin{array}{l}33.7 \\
96.7\end{array}$ & $\begin{array}{l}36.5 \\
54.1\end{array}$ & $\begin{array}{l}34.8 \\
11.2\end{array}$ & $\begin{array}{c}23.7 \\
9.5\end{array}$ & $\begin{array}{l}7.7 \\
3.4\end{array}$ & $\begin{array}{r}10.1 \\
4.1\end{array}$ & $\begin{array}{l}9.9 \\
0.0\end{array}$ \\
\hline $\begin{array}{l}35- \\
\text { Chemicals }\end{array}$ & $\begin{array}{l}\mathrm{t} \\
\mathrm{q}\end{array}$ & $\begin{array}{l}29.1 \\
85.7\end{array}$ & $\begin{array}{l}29.9 \\
54.0\end{array}$ & $\begin{array}{l}27.0 \\
21.1\end{array}$ & $\begin{array}{c}20.5 \\
4.8\end{array}$ & $\begin{array}{c}13.4 \\
0.0\end{array}$ & $\begin{array}{c}14.3 \\
0.0\end{array}$ & $\begin{array}{c}14.4 \\
0.0\end{array}$ \\
\hline $\begin{array}{l}\text { 36-Stone, } \\
\text { Clay, Glass }\end{array}$ & $\mathrm{t}$ & $\begin{array}{l}37.1 \\
99.0\end{array}$ & $\begin{array}{l}38.5 \\
53.1\end{array}$ & $\begin{array}{c}33.8 \\
5.2\end{array}$ & $\begin{array}{c}22.4 \\
0.0\end{array}$ & $\begin{array}{c}13.8 \\
0.0\end{array}$ & $\begin{array}{c}14.3 \\
0.0\end{array}$ & $\begin{array}{c}14.3 \\
0.0\end{array}$ \\
\hline $\begin{array}{l}\text { 37-Basic } \\
\text { Metals }\end{array}$ & $\begin{array}{l}\mathrm{t} \\
\mathrm{q}\end{array}$ & $\begin{array}{l}13.6 \\
93.3\end{array}$ & $\begin{array}{l}16.7 \\
47.4\end{array}$ & $\begin{array}{c}18.4 \\
0.0\end{array}$ & $\begin{array}{c}13.8 \\
0.0\end{array}$ & $\begin{array}{l}7.9 \\
0.0\end{array}$ & $\begin{array}{c}11.0 \\
0.0\end{array}$ & $\begin{array}{c}11.0 \\
0.0\end{array}$ \\
\hline $\begin{array}{l}\text { 38-Metal } \\
\text { Products }\end{array}$ & $\begin{array}{l}\mathrm{t} \\
\mathrm{q}\end{array}$ & $\begin{array}{l}43.1 \\
90.7\end{array}$ & $\begin{array}{l}46.3 \\
74.8\end{array}$ & $\begin{array}{l}30.0 \\
54.7\end{array}$ & $\begin{array}{l}20.8 \\
51.4\end{array}$ & $\begin{array}{l}14.1 \\
42.7\end{array}$ & $\begin{array}{l}15.9 \\
44.1\end{array}$ & $\begin{array}{l}16.1 \\
44.1\end{array}$ \\
\hline $\begin{array}{l}\text { 39-Other } \\
\text { Industries }\end{array}$ & $\mathrm{t}$ & $\begin{array}{r}40.9 \\
100.0\end{array}$ & $\begin{array}{l}42.9 \\
50.0\end{array}$ & $\begin{array}{c}40.5 \\
0.0\end{array}$ & $\begin{array}{c}27.5 \\
0.0\end{array}$ & $\begin{array}{c}17.1 \\
0.0\end{array}$ & $\begin{array}{c}18.1 \\
0.0\end{array}$ & $\begin{array}{c}18.4 \\
0.0\end{array}$ \\
\hline
\end{tabular}

$t=$ Production-weighted average tariff rate. $q=$ Weighted-average share of production subject to import-license requirements. Source: Authors' calculations, SECOFI Sample data. 
Table 3: Average Annual Real Wages in Manufacturing, 1984-1990 (values are in 1980 pesos)

\begin{tabular}{lllllll} 
& \multicolumn{2}{c}{ White-Collar } & \multicolumn{2}{c}{ Blue-Collar } & \multicolumn{2}{r}{$\begin{array}{l}\text { White-Collar/ } \\
\text { Blue-Collar }\end{array}$} \\
Year & $\begin{array}{l}\text { Annual } \\
\text { Earnings }\end{array}$ & $\begin{array}{l}\text { Hourly } \\
\text { Wages }\end{array}$ & $\begin{array}{l}\text { Annual } \\
\text { Earnings }\end{array}$ & $\begin{array}{l}\text { Hourly } \\
\text { Wages }\end{array}$ & $\begin{array}{l}\text { Annual } \\
\text { Earnings }\end{array}$ & $\begin{array}{l}\text { Hourly } \\
\text { Wages }\end{array}$ \\
1984 & 138,793 & 62.127 & 72,528 & 32.191 & 1.914 & 1.930 \\
1985 & 143,692 & 63.856 & 74,952 & 32.783 & 1.917 & 1.948 \\
1986 & 137,444 & 60.641 & 68,525 & 29.929 & 2.006 & 2.027 \\
1987 & 134,474 & 59.014 & 67,559 & 29.243 & 1.991 & 2.018 \\
1988 & 122,241 & 53.557 & 57,781 & 24.729 & 2.116 & 2.166 \\
1989 & 145,487 & 64.278 & 62,755 & 26.809 & 2.318 & 2.398 \\
1990 & 160,502 & 70.460 & 64,935 & 27.691 & 2.472 & 2.545
\end{tabular}

Source: Authors' calculations based on SECOFI sample data. 
Table 4:

White-Collar Average Wage/Blue-Collar Average Wage

By Two-Digit Industry, 1984 and 1990

\begin{tabular}{|c|c|c|c|c|c|}
\hline \multirow[b]{2}{*}{ ISIC } & \multirow[b]{2}{*}{ Year } & \multicolumn{2}{|c|}{ Relative Annual Earnings } & \multicolumn{2}{|c|}{ Relative Hourly Wage } \\
\hline & & Level & $\underline{\text { Log Change }}$ & $\underline{\text { Level }}$ & Log Change \\
\hline 31 & 1984 & 1.831 & & 1.832 & \\
\hline 31 & 1990 & 2.314 & 0.234 & 2.350 & 0.249 \\
\hline 32 & 1984 & 1.658 & & 1.526 & \\
\hline 32 & 1990 & 1.964 & 0.169 & 1.951 & 0.246 \\
\hline 33 & 1984 & 1.823 & & 1.895 & \\
\hline 33 & 1990 & 2.227 & 0.200 & 2.275 & 0.183 \\
\hline 34 & 1984 & 1.797 & & 1.866 & \\
\hline 34 & 1990 & 2.452 & 0.310 & 2.592 & 0.329 \\
\hline 35 & 1984 & 1.844 & & 1.991 & \\
\hline 35 & 1990 & 2.274 & 0.210 & 2.392 & 0.183 \\
\hline 36 & 1984 & 2.048 & & 2.083 & \\
\hline 36 & 1990 & 3.060 & 0.401 & 3.149 & 0.413 \\
\hline 37 & 1984 & 1.676 & & 1.593 & \\
\hline 37 & 1990 & 2.552 & 0.421 & 2.597 & 0.488 \\
\hline 38 & 1984 & 2.020 & & 2.039 & \\
\hline 38 & 1990 & 2.478 & 0.204 & 2.544 & 0.221 \\
\hline 39 & 1984 & 2.936 & & 3.044 & \\
\hline 39 & 1990 & 3.928 & 0.291 & 3.992 & 0.271 \\
\hline
\end{tabular}

Source: Authors' calculations based on SECOFI sample data. 
Table 5: Industrial Census Data:

Relative Wages and Employment and Industry Employment Shares, 1985 and 1988

\begin{tabular}{|c|c|c|c|c|c|c|}
\hline \multirow[b]{2}{*}{ ISIC } & \multirow[b]{2}{*}{ Year } & \multirow{2}{*}{\multicolumn{2}{|c|}{$\begin{array}{l}\text { White Collar/Blue Collar } \\
\text { Annual Wage Emoloyment }\end{array}$}} & \multicolumn{3}{|c|}{ Industry Share of Nat'1 Employment } \\
\hline & & & & White & Blue Collar & Total \\
\hline 31 & 1985 & 1.846 & 0.390 & 0.210 & 0.186 & 0.208 \\
\hline 31 & 1988 & 1.838 & 0.382 & 0.215 & 0.184 & 0.206 \\
\hline 32 & 1985 & 1.721 & 0.208 & 0.107 & 0.178 & 0.156 \\
\hline 32 & 1988 & 1.870 & 0.205 & 0.113 & 0.181 & 0.160 \\
\hline 33 & 1985 & 1.230 & 0.245 & 0.034 & 0.047 & 0.049 \\
\hline 33 & 1988 & 1.983 & 0.171 & 0.027 & 0.052 & 0.051 \\
\hline 34 & 1985 & 1.505 & 0.468 & 0.065 & 0.048 & 0.052 \\
\hline 34 & 1988 & 1.699 & 0.509 & 0.074 & 0.048 & 0.054 \\
\hline 35 & 1985 & 1.633 & 0.452 & 0.181 & 0.139 & 0.140 \\
\hline 35 & 1988 & 1.693 & 0.449 & 0.180 & 0.131 & 0.135 \\
\hline 36 & 1985 & 1.963 & 0.282 & 0.045 & 0.055 & 0.055 \\
\hline 36 & 1988 & 2.567 & 0.275 & 0.045 & 0.054 & 0.057 \\
\hline 37 & 1985 & 1.593 & 0.350 & 0.051 & 0.051 & 0.048 \\
\hline 37 & 1988 & 2.245 & 0.371 & 0.044 & 0.039 & 0.038 \\
\hline 38 & 1985 & 2.018 & 0.361 & 0.298 & 0.286 & 0.282 \\
\hline 38 & 1988 & 2.607 & 0.319 & 0.291 & 0.299 & 0.288 \\
\hline 39 & 1985 & 2.704 & 0.292 & 0.009 & 0.011 & 0.010 \\
\hline 39 & 1988 & 2.444 & 0.285 & 0.011 & 0.012 & 0.012 \\
\hline
\end{tabular}

Source: Authors' calculations based on Industrial Census data. 
Table 6: Relative Employment, All Manufacturing, 1984-1990

Number of Workers

Blue-

Collar

White-

Collar Ratio

234,851

545,477

.431

.428

.440

.442

.443

.439

.433

$250,066 \quad 577,405$

.0569

.0628 '000's of Hours Worked

Blue- White-

Collar Collar Ratio

$\begin{array}{lll}524,666 & 1,229,016 & .427\end{array}$

$\begin{array}{lll}539,713 & 1,282,056 & .421\end{array}$

$\begin{array}{lll}548,925 & 1,261,465 & .435\end{array}$

$\begin{array}{lll}550,368 & 1,261,272 & .436\end{array}$

$\begin{array}{lll}556,327 & 1,284,741 & .433\end{array}$

$\begin{array}{lll}563,229 & 1,326,644 & .425\end{array}$

$569,629 \quad 1,353,991$

.421

log change

1984-90

.0823

.0969

Source: Authors' calculations based on SECOFI sample data. 
Table 7:

White-Collar Average Employment/Blue-Collar Average Employment

By Two-Digit Industry, 1984 and 1990

\begin{tabular}{|c|c|c|c|c|c|}
\hline \multirow[b]{2}{*}{$\underline{\text { ISIC }}$} & \multirow[b]{2}{*}{ Year } & \multicolumn{2}{|c|}{ Relative No. of Workers } & \multicolumn{2}{|c|}{ Relative Total Hours } \\
\hline & & Level & Change & Level & Change \\
\hline 31 & 1984 & 0.441 & & 0.441 & \\
\hline 31 & 1990 & 0.408 & -0.033 & 0.402 & -0.039 \\
\hline 32 & 1984 & 0.256 & & 0.278 & \\
\hline 32 & 1990 & 0.269 & 0.013 & 0.271 & -0.007 \\
\hline 33 & 1984 & 0.331 & & 0.319 & \\
\hline 33 & 1990 & 0.321 & -0.010 & 0.314 & -0.005 \\
\hline 34 & 1984 & 0.372 & & 0.358 & \\
\hline 34 & 1990 & 0.379 & 0.008 & 0.359 & 0.000 \\
\hline 35 & 1984 & 0.661 & & 0.612 & \\
\hline 35 & 1990 & 0.695 & 0.034 & 0.660 & 0.049 \\
\hline 36 & 1984 & 0.367 & & 0.361 & \\
\hline 36 & 1990 & 0.380 & 0.013 & 0.370 & 0.009 \\
\hline 37 & 1984 & 0.386 & & 0.406 & \\
\hline 37 & 1990 & 0.427 & 0.041 & 0.419 & 0.013 \\
\hline 38 & 1984 & 0.424 & & 0.420 & \\
\hline 38 & 1990 & 0.405 & -0.018 & 0.395 & -0.025 \\
\hline 39 & 1984 & 0.459 & & 0.443 & \\
\hline 39 & 1990 & 0.424 & -0.035 & 0.417 & -0.026 \\
\hline
\end{tabular}

Source: Authors' calculations based on SECOFI sample data. 
Table 8: Industry Shares of Total Employment by Worker Type, 1984 and 1990

\begin{tabular}{|c|c|c|c|c|c|c|c|}
\hline$\underline{\text { ISIC }}$ & Year & $\begin{array}{l}\text { White } \\
\text { Level }\end{array}$ & $\begin{array}{l}\text { Collar } \\
\text { Change }\end{array}$ & $\begin{array}{l}\text { Blue- } \\
\text { Level }\end{array}$ & $\begin{array}{l}\text { Collar } \\
\text { Change }\end{array}$ & $\begin{array}{l}\text { Total } \\
\text { Level }\end{array}$ & $\begin{array}{l}\text { Employment } \\
\text { Change }\end{array}$ \\
\hline 31 & 1984 & 0.198 & & 0.193 & & 0.195 & \\
\hline 31 & 1990 & 0.203 & 0.005 & 0.215 & 0.022 & 0.214 & 0.019 \\
\hline 32 & 1984 & 0.087 & & 0.146 & & 0.128 & \\
\hline 32 & 1990 & 0.079 & -0.008 & 0.127 & -0.019 & 0.112 & -0.016 \\
\hline 33 & 1984 & 0.012 & & 0.015 & & 0.014 & \\
\hline 33 & 1990 & 0.011 & -0.000 & 0.014 & -0.000 & 0.013 & -0.000 \\
\hline 34 & 1984 & 0.047 & & 0.055 & & 0.052 & \\
\hline 34 & 1990 & 0.044 & -0.003 & 0.051 & -0.004 & 0.048 & -0.004 \\
\hline 35 & 1984 & 0.253 & & 0.165 & & 0.191 & \\
\hline 35 & 1990 & 0.262 & 0.009 & 0.163 & -0.002 & 0.193 & 0.001 \\
\hline 36 & 1984 & 0.063 & & 0.074 & & 0.071 & \\
\hline 36 & 1990 & 0.065 & 0.002 & 0.074 & -0.000 & 0.071 & 0.000 \\
\hline 37 & 1984 & 0.070 & & 0.078 & & 0.075 & \\
\hline 37 & 1990 & 0.060 & -0.009 & 0.061 & -0.016 & 0.061 & -0.014 \\
\hline 38 & 1984 & 0.263 & & 0.268 & & 0.266 & \\
\hline 38 & 1990 & 0.269 & 0.005 & 0.287 & 0.020 & 0.281 & 0.014 \\
\hline 39 & 1984 & 0.007 & & 0.007 & & 0.007 & \\
\hline 39 & 1990 & 0.008 & 0.000 & 0.008 & 0.001 & 0.008 & 0.000 \\
\hline
\end{tabular}

Source: Authors' calculations based on SECOFI sample data. 
Table 9a: Decomposing Sector Changes into Within and Between Industries

\begin{tabular}{||l|c|c|c||}
\hline & $\begin{array}{l}\text { Change in White- } \\
\text { Collar Wage Share }\end{array}$ & $\begin{array}{l}\text { Within-Industry } \\
\text { Wage-Share Change }\end{array}$ & $\begin{array}{l}\text { Between-Industry } \\
\text { Wage Share } \\
\text { Changes }\end{array}$ \\
\hline $\begin{array}{l}\text { SECOFI Sample } \\
(1984-1990)\end{array}$ & 0.067 & 0.054 & 0.013 \\
\hline $\begin{array}{l}\text { Industrial Census } \\
(1985-1988)\end{array}$ & 0.026 & 0.024 & 0.002 \\
\hline
\end{tabular}

Table 9b: Decomposing Plant Changes into Within and Between Plants

\begin{tabular}{|l|c|c|c|}
\hline & $\begin{array}{l}\text { Change in White- } \\
\text { Collar Wage Share }\end{array}$ & $\begin{array}{l}\text { Within-Plant Change } \\
\text { in the Wage-Share }\end{array}$ & $\begin{array}{l}\text { Between-Plant } \\
\text { Wage-Share } \\
\text { Changes }\end{array}$ \\
\hline $\begin{array}{l}\text { SECOFI Sample } \\
(1984-1990)\end{array}$ & 0.067 & 0.049 & 0.019 \\
\hline
\end{tabular}


Table 10: Variation in Wages and Employment Across Sectors (standard errors in parentheses)

\begin{tabular}{|c|c|c|c|c|}
\hline \multirow{2}{*}{$\begin{array}{l}\text { Independent } \\
\text { Variables }\end{array}$} & \multicolumn{4}{|c|}{ Dependent Variable } \\
\hline & $\begin{array}{l}\text { White-Collar/ } \\
\text { Blue-Collar } \\
\text { Annual Wage }\end{array}$ & $\begin{array}{l}\text { White-Collar/ } \\
\text { Blue-Collar } \\
\text { Hourly Wage }\end{array}$ & $\begin{array}{l}\text { White-Collar/ } \\
\text { Blue-Collar } \\
\text { Annual } \\
\text { Employment }\end{array}$ & $\begin{array}{l}\text { White-Collar/ } \\
\text { Blue-Collar } \\
\text { Total Hours }\end{array}$ \\
\hline Average Plant Size: & & & & \\
\hline 51 to 100 Workers & $\begin{array}{c}.0347 \\
(.0933)\end{array}$ & $\begin{array}{c}.0803 \\
(.1043)\end{array}$ & $\begin{array}{c}.0894 \\
(.1793)\end{array}$ & $\begin{array}{c}.0438 \\
(.1796)\end{array}$ \\
\hline 101 to 250 Workers & $\begin{array}{c}.0887 \\
(.0898)\end{array}$ & $\begin{array}{c}.1317 \\
(.1004)\end{array}$ & $\begin{array}{c}.2537 \\
(.1725)\end{array}$ & $\begin{array}{c}.2107 \\
(.1728)\end{array}$ \\
\hline 251 to 500 Workers & $\begin{array}{c}.0732 \\
(.0913)\end{array}$ & $\begin{array}{l}.1095 \\
(.1021)\end{array}$ & $\begin{array}{c}.0552 \\
(.1754)\end{array}$ & $\begin{array}{c}.0189 \\
(.1757)\end{array}$ \\
\hline 501 to 750 Workers & $\begin{array}{c}.0423 \\
(.0920)\end{array}$ & $\begin{array}{c}.0688 \\
(.1029)\end{array}$ & $\begin{array}{c}.0708 \\
(.1768)\end{array}$ & $\begin{array}{c}.0443 \\
(.1771)\end{array}$ \\
\hline$>750$ Workers & $\begin{array}{c}.0700 \\
(.0948)\end{array}$ & $\begin{array}{c}.0909 \\
(.1059)\end{array}$ & $\begin{array}{l}.0464 \\
(.1821)\end{array}$ & $\begin{array}{c}.0256 \\
(.1824)\end{array}$ \\
\hline Capital-Labor Ratio: & & & & \\
\hline 2nd Quintile & $\begin{array}{c}-.0013 \\
(.0250)\end{array}$ & $\begin{array}{c}-.0131 \\
(.0279)\end{array}$ & $\begin{array}{c}.0614 \\
(.0480)\end{array}$ & $\begin{array}{c}.0632 \\
(.0480)\end{array}$ \\
\hline 3rd Quintile & $\begin{array}{c}.0125 \\
(.0263)\end{array}$ & $\begin{array}{c}.0290 \\
(.0294)\end{array}$ & $\begin{array}{l}2132^{\circ} \\
(.0506)\end{array}$ & $\begin{array}{l}.1967^{*} \\
(.0507)\end{array}$ \\
\hline 4th Quintile & $\begin{array}{c}.0127 \\
(.0285)\end{array}$ & $\begin{array}{c}.0052 \\
(.0318)\end{array}$ & $\begin{array}{l}.1961^{*} \\
(.0547)\end{array}$ & $\begin{array}{l}.2036 \\
(.0548)\end{array}$ \\
\hline 5th Quintile & $\begin{array}{c}-0.0466 \\
(.0335)\end{array}$ & $\begin{array}{c}-.0488 \\
(.0374)\end{array}$ & $\begin{array}{c}.0789 \\
(.0643)\end{array}$ & $\begin{array}{c}.0810 \\
(.0644)\end{array}$ \\
\hline Export Share & $\begin{array}{l}.2146^{* *} \\
(.0579)\end{array}$ & $\begin{array}{l}.2066^{* *} \\
(.0647)\end{array}$ & $\begin{array}{c}.0116 \\
(.1112)\end{array}$ & $\begin{array}{l}.0196 \\
(.1114)\end{array}$ \\
\hline Foreign Share & $\begin{array}{l}.1125^{*} \\
(.0347)\end{array}$ & $\begin{array}{l}.1464^{* *} \\
(.0388)\end{array}$ & $\begin{array}{l}.2645^{* *} \\
(.0668)\end{array}$ & $\begin{array}{l}.2306^{* *} \\
(.0669)\end{array}$ \\
\hline Social Security & $\begin{array}{l}-2.726^{\circ} \\
(.4219)\end{array}$ & $\begin{array}{l}-3.079^{* *} \\
(.4717)\end{array}$ & $\begin{array}{c}-3.4692^{* *} \\
(.8106)\end{array}$ & $\begin{array}{l}-3.1161^{\circ} \\
(.8120)\end{array}$ \\
\hline $\begin{array}{l}\text { Other Non-wage } \\
\text { Costs }\end{array}$ & $\begin{array}{l}-.5433^{* *} \\
(.1791)\end{array}$ & $\begin{array}{l}-.4763^{\circ \prime} \\
(.2002)\end{array}$ & $\begin{array}{l}-.3590 \\
(.3441)\end{array}$ & $\begin{array}{l}-.4260 \\
(.3447)\end{array}$ \\
\hline Profit Sharing & $\begin{array}{l}.3823^{\circ *} \\
(.1863)\end{array}$ & $\begin{array}{l}.4753^{\circ} \\
(.2083)\end{array}$ & $\begin{array}{l}1.1270^{\circ} \\
(.3581)\end{array}$ & $\begin{array}{l}1.0340^{\circ} \\
(.3587)\end{array}$ \\
\hline $\begin{array}{l}\text { Imported Machinery/ } \\
\text { Machinery } \\
\text { Purchases }\end{array}$ & $\begin{array}{c}.0551 \\
(.0442)\end{array}$ & $\begin{array}{c}.0524 \\
(.0494)\end{array}$ & $\begin{array}{l}-.1422 \\
(.0849)\end{array}$ & $\begin{array}{l}-.1395 \\
(.0850)\end{array}$ \\
\hline
\end{tabular}

" Indicates significance at the five-percent level. 
Table 10 (Continued)

(standard errors in parentheses)

\begin{tabular}{||l|c|c|c|c||}
\hline \multirow{2}{*}{ Variable } & \multicolumn{4}{|c||}{ Dependent Variable } \\
\cline { 2 - 5 } & $\begin{array}{c}\text { White-Collar/ } \\
\text { Blue-Collar } \\
\text { Annual Wage }\end{array}$ & $\begin{array}{c}\text { White-Collar/ } \\
\text { Blue-Collar } \\
\text { Hourly Wage }\end{array}$ & $\begin{array}{c}\text { White-Collar/ } \\
\text { Blue-Collar } \\
\text { Annual } \\
\text { Employment }\end{array}$ & $\begin{array}{c}\text { White-Collar/ } \\
\text { Blue-Collar } \\
\text { Total Hours }\end{array}$ \\
\hline Imported Raw Mat- & $-.1621^{* *}$ & $-.2218^{* *}$ & $.6764^{* *}$ & $.7362^{* *}$ \\
erial/Materials & $. .0773)$ & $(.0864)$ & $(.1485)$ & $(.1488)$ \\
Equipment Share in & .0173 & .0359 & $-.2569^{* *}$ & $-.2755^{* *}$ \\
Investment & $(.0457)$ & $(.0511)$ & $(.0878)$ & $(.0880)$ \\
Transport Share in & -.1366 & -.0853 & $.6606^{* *}$ & $.6092^{*}$ \\
Investment & $(.0847)$ & $(.0947)$ & $(.1628)$ & $(.1631)$ \\
(Lag) Total Factor & .0329 & .0425 & -.0293 & -.0389 \\
Productvty Growth & $(.0566)$ & $(.0633)$ & $(.1088)$ & $(.1090)$ \\
Royalties Paid & $-.2655^{* *}$ & $-.2517^{* *}$ & $.5280^{* *}$ & $.5142^{* *}$ \\
Tariffs & $(.0679)$ & $(.0759)$ & $(.1304)$ & $(.1306)$ \\
Quota Coverage & .0009 & .0012 & $-.0088^{* *}$ & $-.0091^{* *}$ \\
Tariffs*Quotas & $(.0014)$ & $(.0016)$ & $(.0027)$ & $(.0027)$ \\
& -.0005 & -.0003 & .0004 & .0002 \\
Adj R-Square & $(.0007)$ & $(.0008)$ & $(.0013)$ & $(.0013)$ \\
No of Obs. & .0000 & .0000 & .0000 & .0000 \\
& $(.0000)$ & $(.0000)$ & $(.0000)$ & $(.0000)$ \\
\hline
\end{tabular}

" Indicates significance at the five-percent level.

Note: All specifications include time dummies, industry dummies and state dummies. 
Table 11: Variation in Wages and Employment Across Plants (standard errors in parentheses)

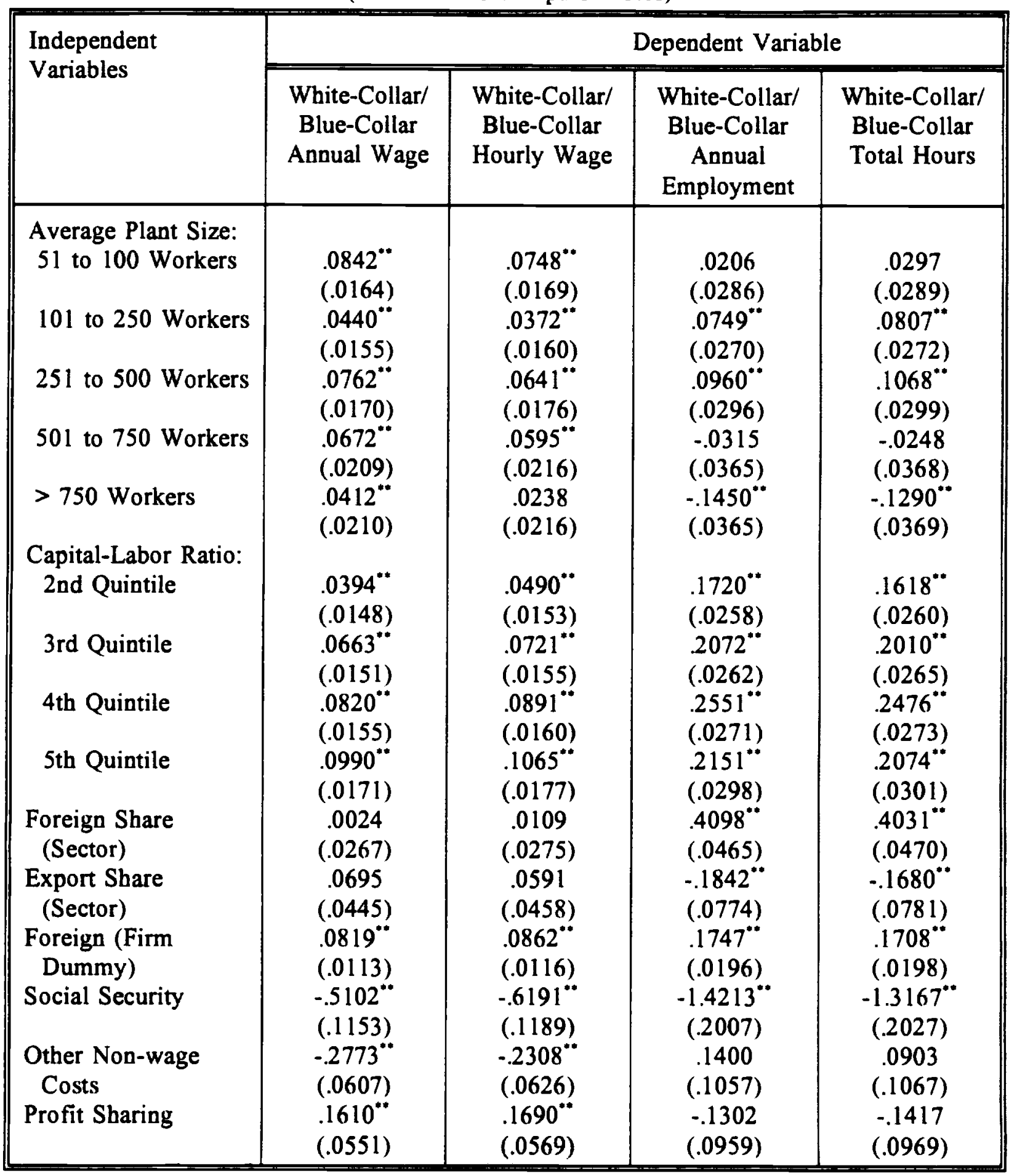

" Indicates significance at the five-percent level. 
Table 11 (Continued)

(standard errors in parentheses)

\begin{tabular}{|c|c|c|c|c|}
\hline \multirow[t]{2}{*}{ Variable } & \multicolumn{4}{|c|}{ Dependent Variable } \\
\hline & $\begin{array}{l}\text { White-Collar/ } \\
\text { Blue-Collar } \\
\text { Annual Wage }\end{array}$ & $\begin{array}{l}\text { White-Collar/ } \\
\text { Blue-Collar } \\
\text { Hourly Wage }\end{array}$ & $\begin{array}{l}\text { White-Collar/ } \\
\text { Blue-Collar } \\
\text { Annual } \\
\text { Employment }\end{array}$ & $\begin{array}{l}\text { White-Collar/ } \\
\text { Blue-Collar } \\
\text { Total Hours }\end{array}$ \\
\hline Imported Machinery/ & .0089 & .0149 & $-.0984^{* *}$ & $-.1055^{* *}$ \\
\hline Total Machinery & $(.0215)$ & $(.0221)$ & $(.0374)$ & $(.0378)$ \\
\hline Imported Material & $.0657^{* *}$ & .0420 & $.4238^{* *}$ & $.4512^{* *}$ \\
\hline Share & $(.0308)$ & $(.0317)$ & $(.0536)$ & $(.0541)$ \\
\hline $\begin{array}{l}\text { Equipment Share in } \\
\text { Investment }\end{array}$ & $\begin{array}{c}.0016 \\
(.0149)\end{array}$ & $\begin{array}{c}.0083 \\
(.0153)\end{array}$ & $\begin{array}{l}-.1592^{\circ *} \\
(.0259)\end{array}$ & $\begin{array}{l}-.1657^{* *} \\
(.0262)\end{array}$ \\
\hline Transport Share in & .0123 & .0223 & .0553 & .0463 \\
\hline Investment & $(.0172)$ & $(.0178)$ & $(.0300)$ & $(.0303)$ \\
\hline (Lag) Total Factor & .0012 & .0034 & .0090 & .0073 \\
\hline Productvty Growth & $(.0110)$ & $(.0113)$ & $(.0191)$ & $(.0193)$ \\
\hline Export (Firm & $.0596^{* *}$ & $.0598^{* *}$ & -.0039 & -.0048 \\
\hline Dummy) & $(.0112)$ & $(.0116)$ & $(.0196)$ & $(.0198)$ \\
\hline Royalties Paid & .0446 & .0425 & .0919 & .0942 \\
\hline & $(.0306)$ & $(.0316)$ & $(.0533)$ & $(.0539)$ \\
\hline Tariffs & .0007 & .0003 & $-.0046^{\circ}$ & $-.0042^{* *}$ \\
\hline & $(.0009)$ & $(.0009)$ & $(.0015)$ & $(.0016)$ \\
\hline Quota Coverage & $\begin{array}{c}-.0004 \\
(.0005)\end{array}$ & $\begin{array}{l}-.0008 \\
(.0005)\end{array}$ & $\begin{array}{c}.0001 \\
(.0009)\end{array}$ & $\begin{array}{c}.0005 \\
(0009)\end{array}$ \\
\hline Tariffs*Quotas & .0000 & .0000 & .0000 & .0000 \\
\hline & $(.0000)$ & $(.0000)$ & $(.0000)$ & $(.0000)$ \\
\hline Adj R-Square & .13 & .14 & .32 & .31 \\
\hline No of Obs. & 8690 & 8698 & 8691 & 8699 \\
\hline
\end{tabular}

"* Indicates significance at the five-percent level.

Note: All specifications include time dummies, industry dummies and state dummies. 


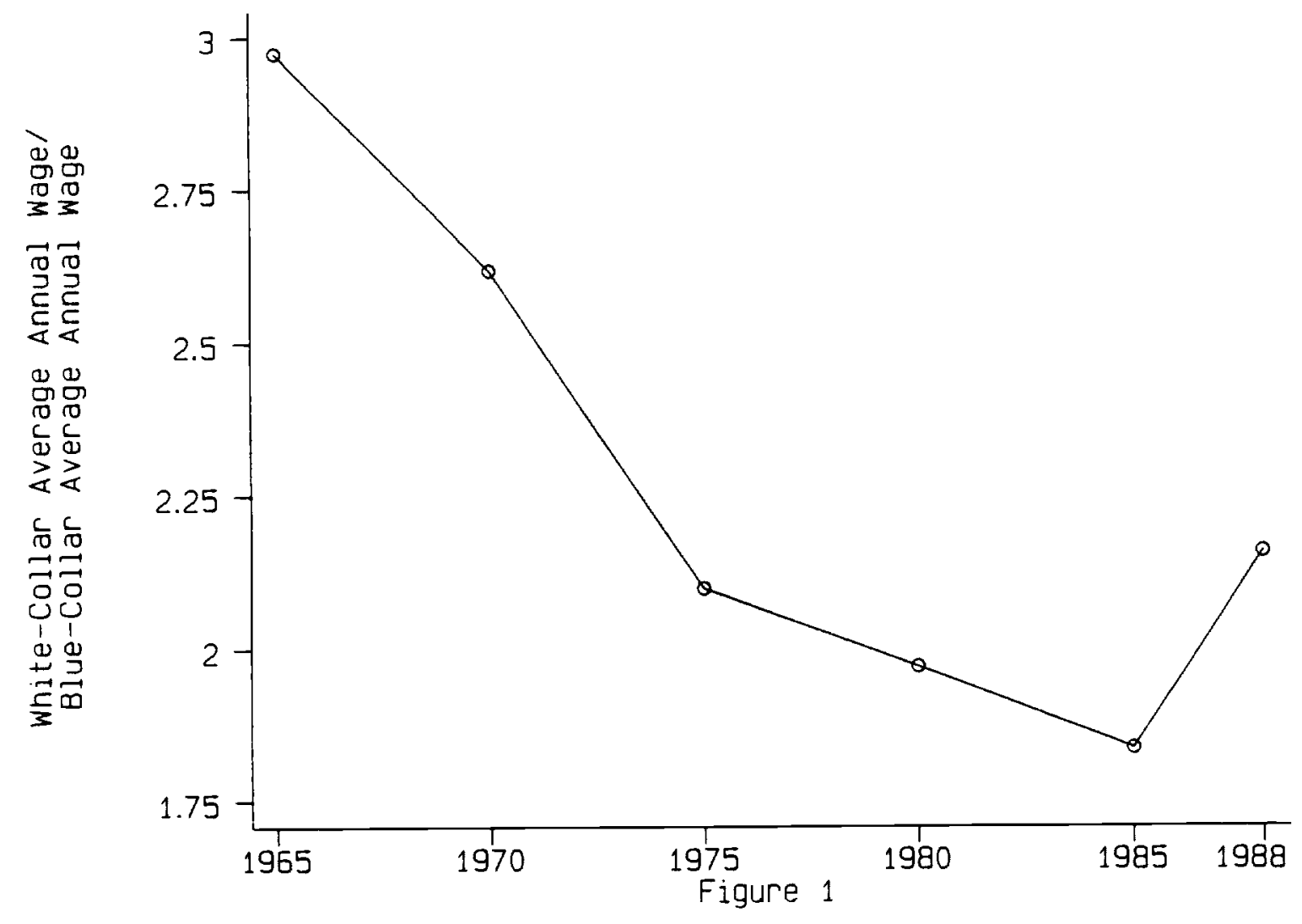


White-Collar Employment/Blue-Collar Employment

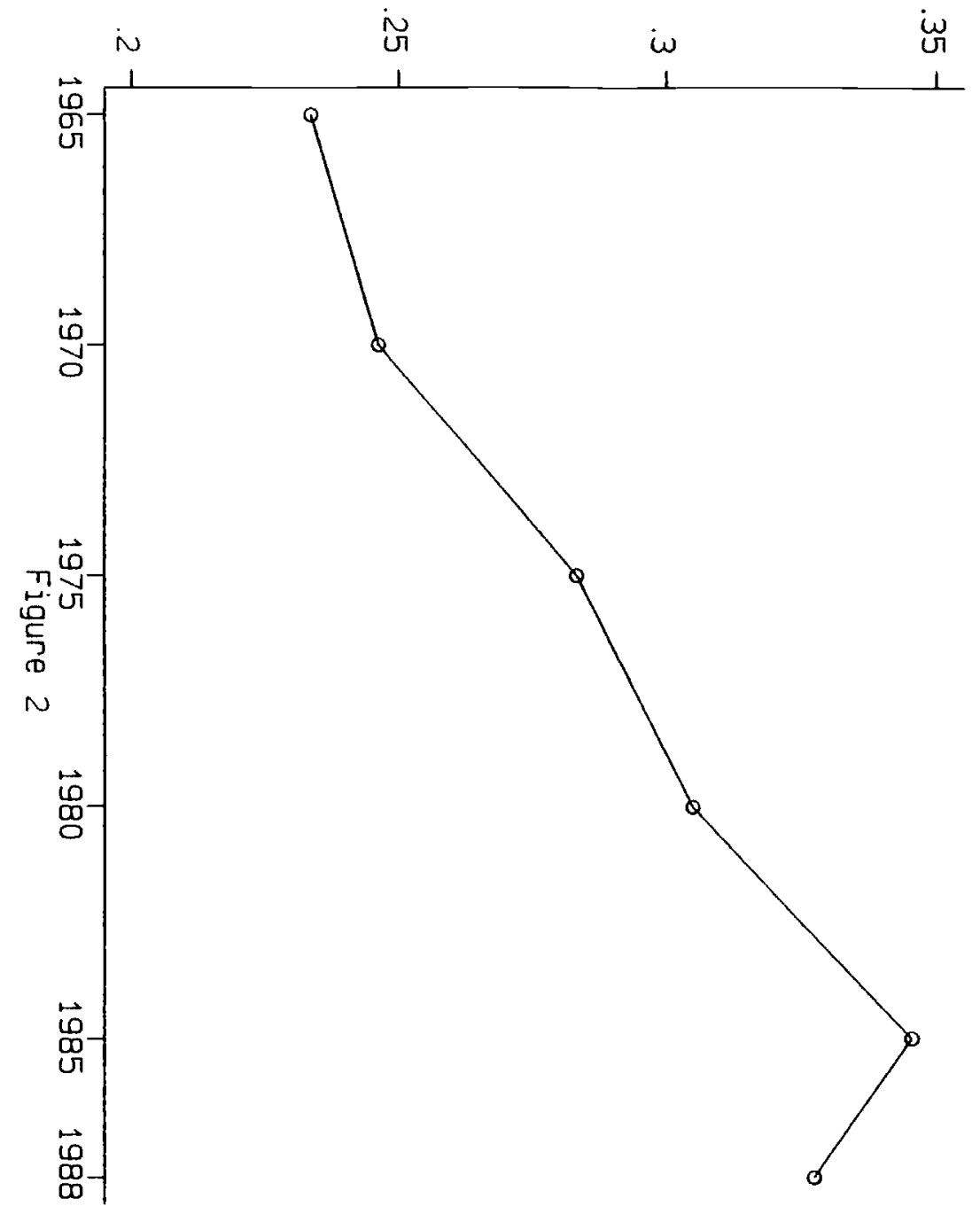




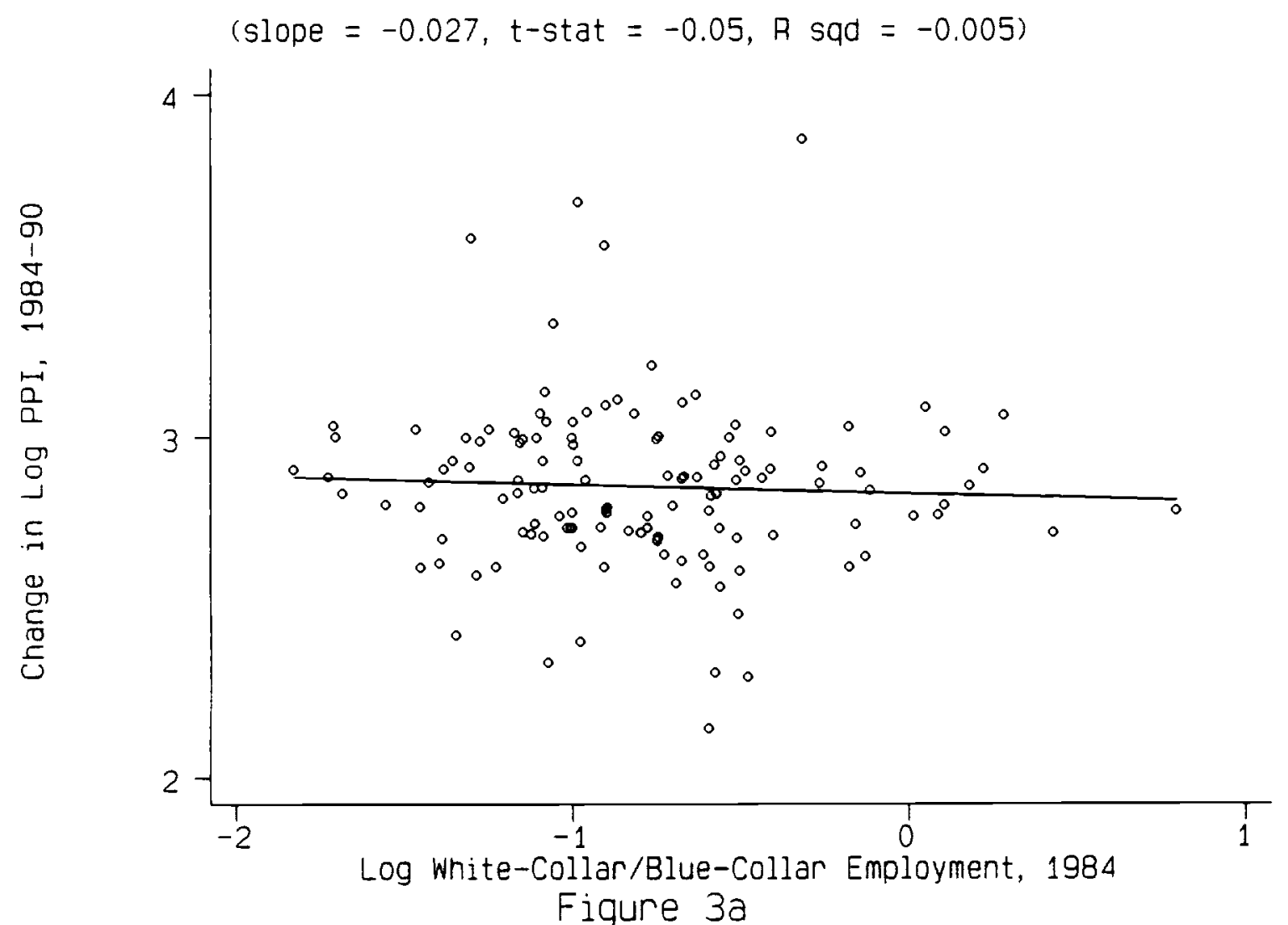




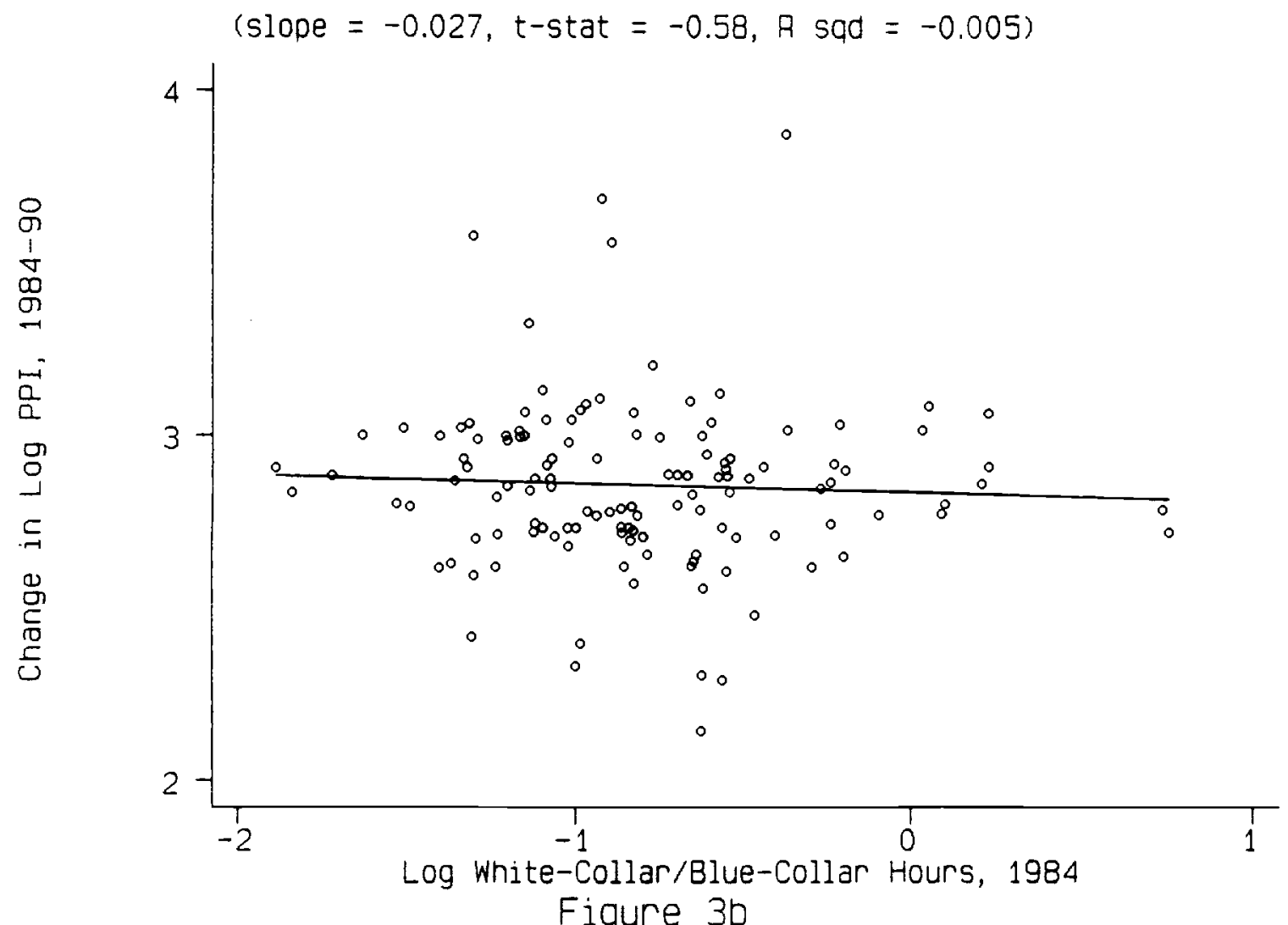

Figure 3b 


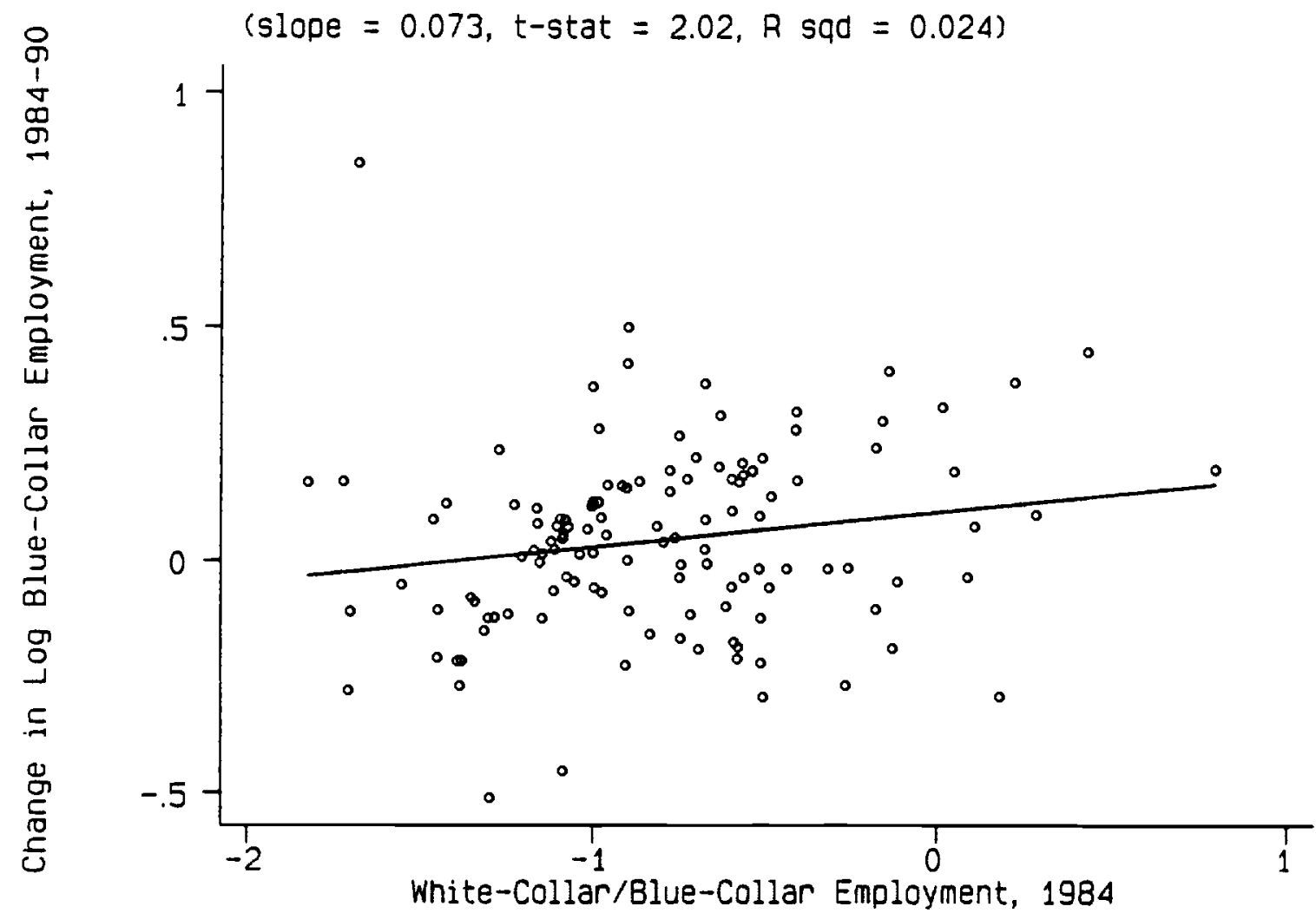

Figure $4 a$ 


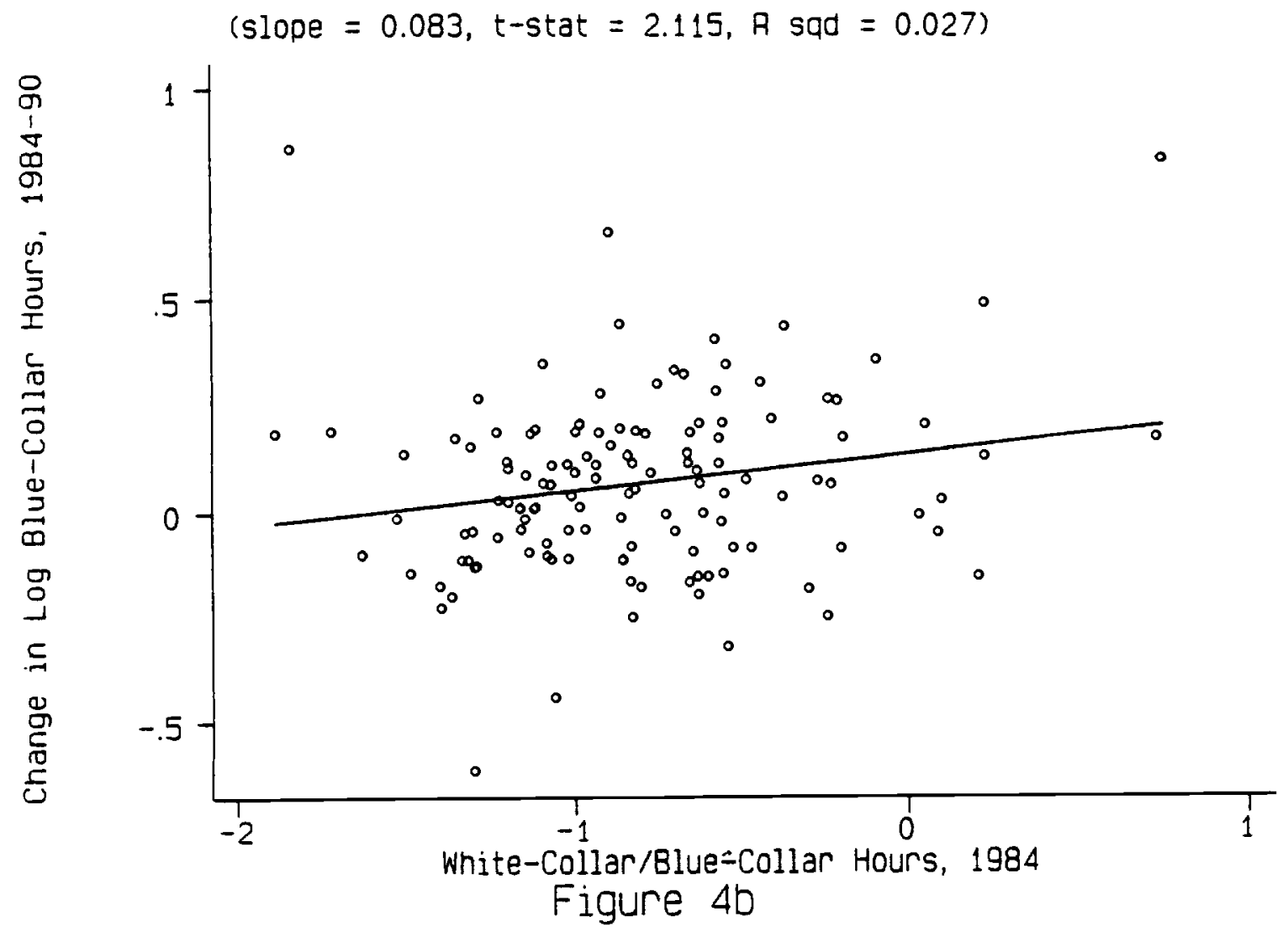




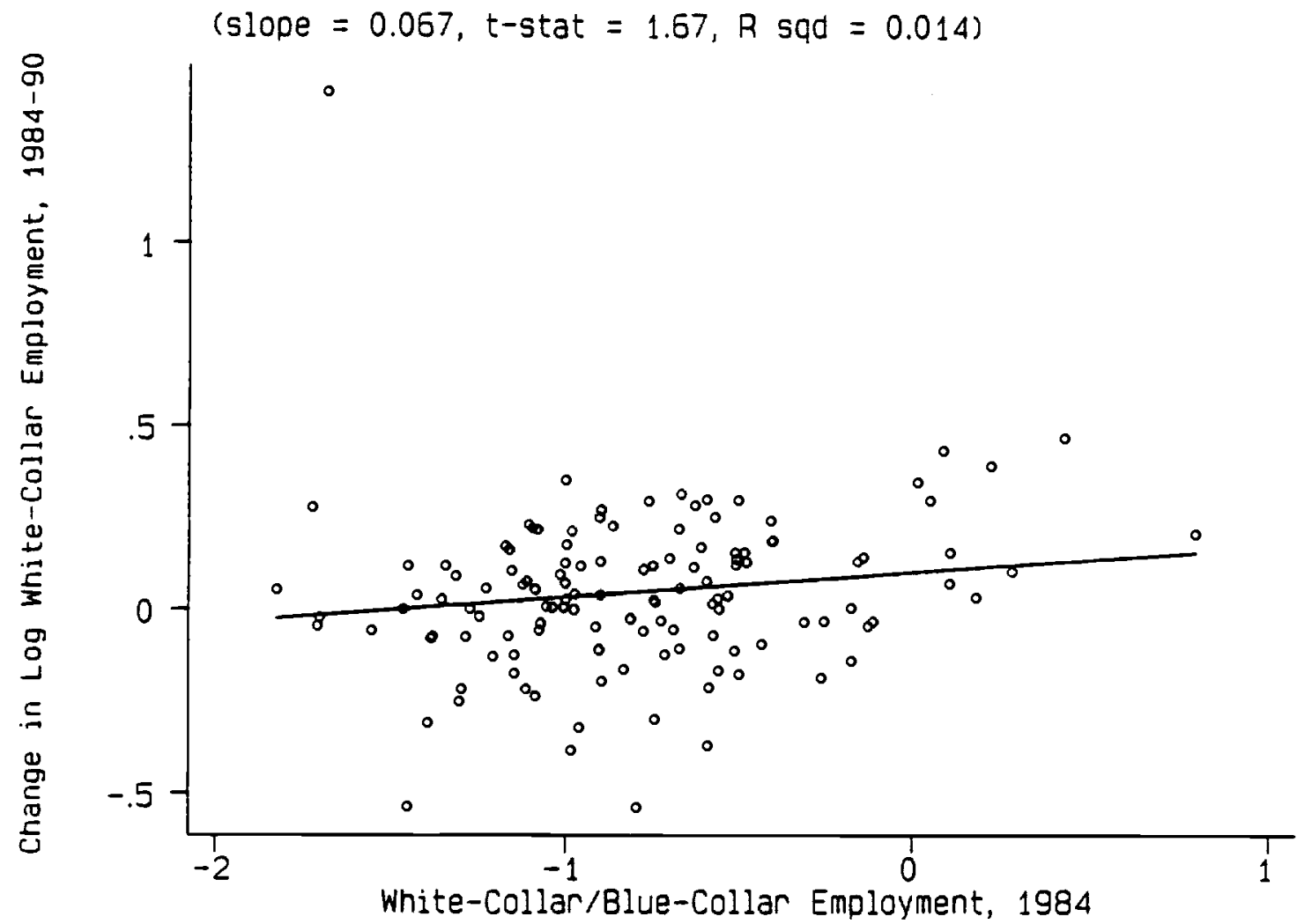

Figure $5 a$ 


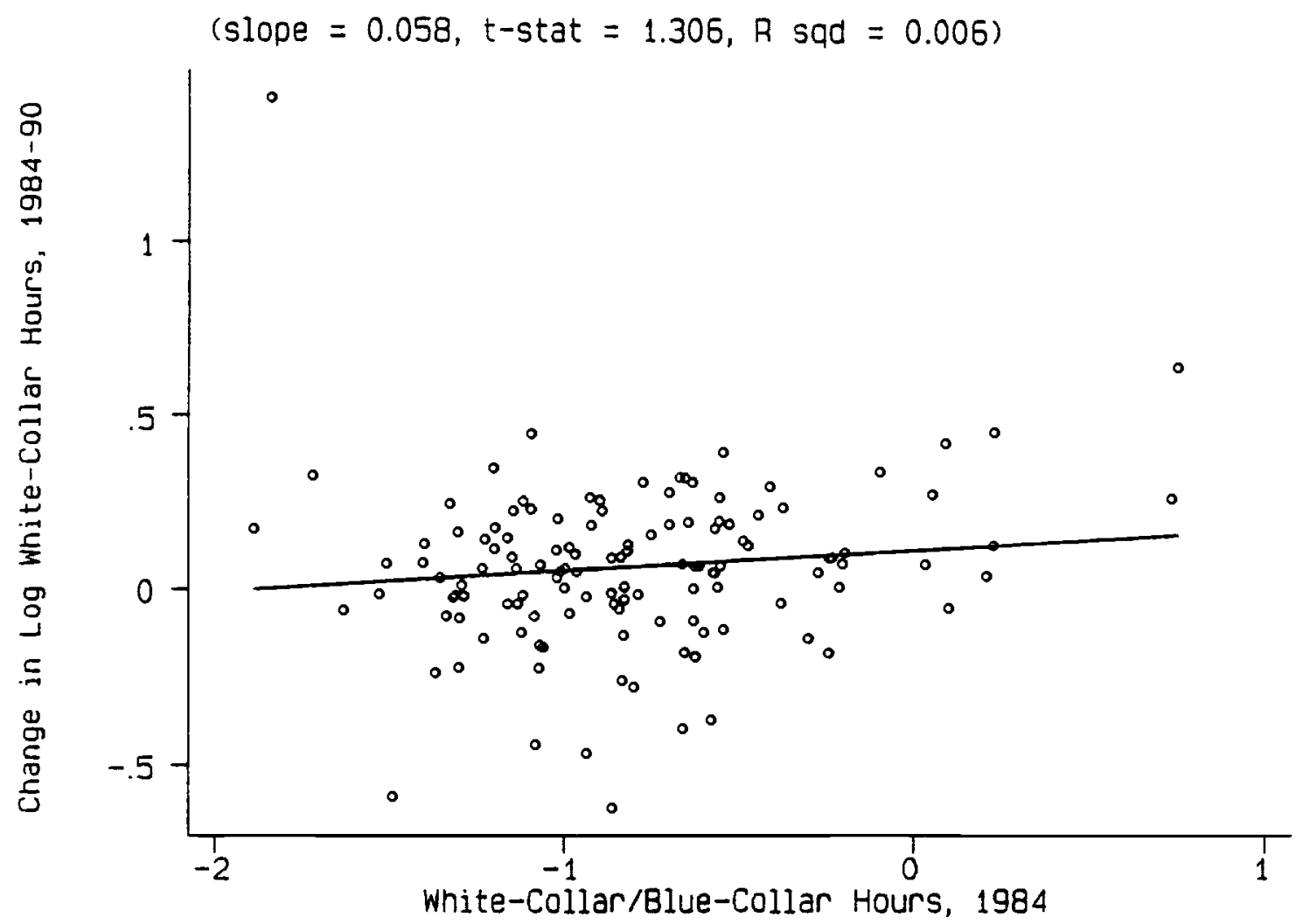

Figure 5b 


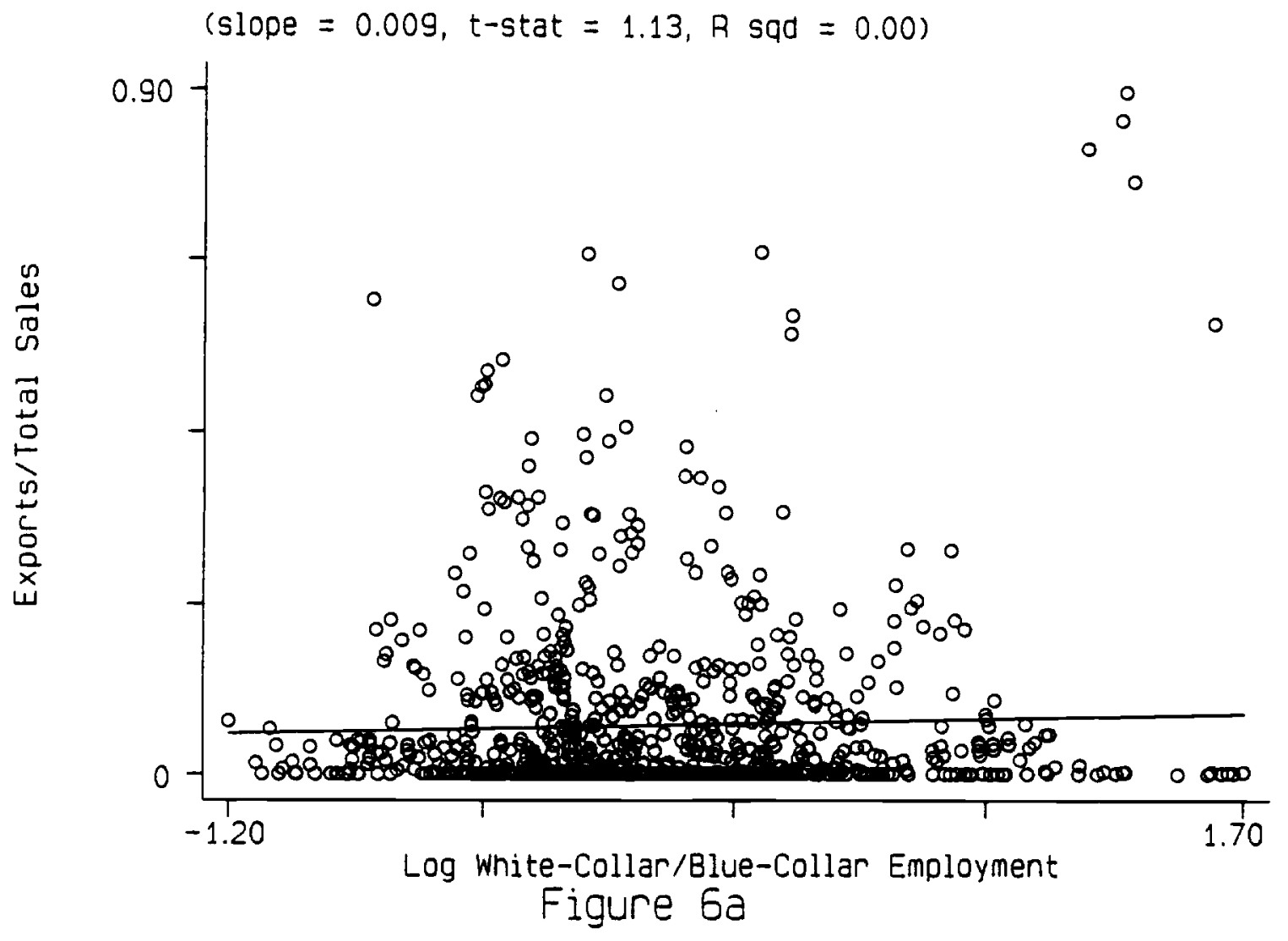




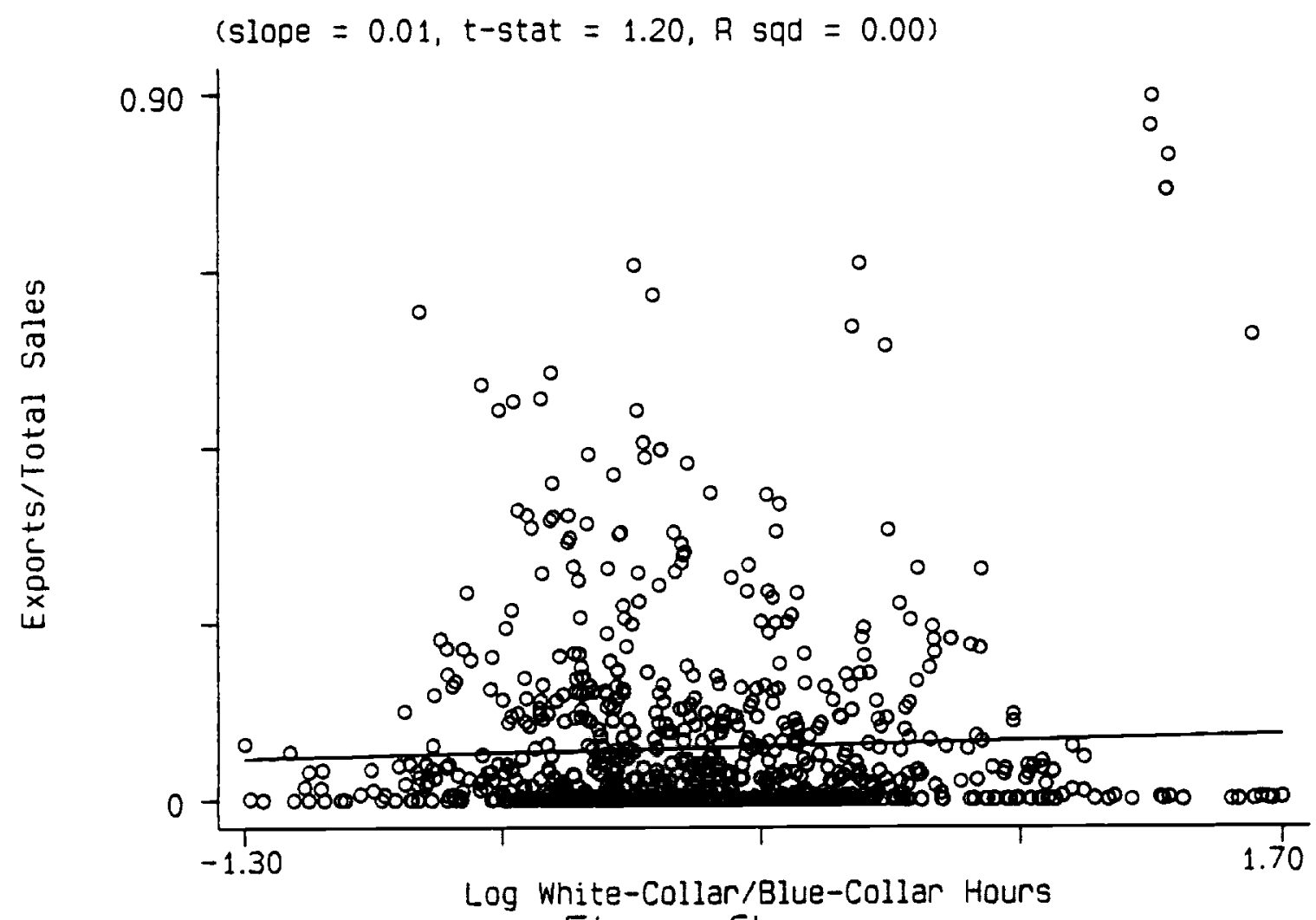

Figure 6b 